\title{
Üniversitelerin Sağlık Yönetimi Programlarında Muhasebe ve Finans Derslerinin Yeri ve Türkiye Uygulaması
}

(Araştırma Makalesi)

The Place of Accounting and Finance Courses in Health Management Programs of Universities and Turkey Practice

Doi: 10.29023/alanyaakademik.550708

Ali Bertan SAVAŞ

Başkent Üniversitesi, Sosyal Bilimler Enstitüsü, Muhasebe ve Finansman Doktora Programı, bertan.006@gmail.com

Orcid No: 0000-0002-1176-6867

\section{Vedat EKERGIL}

Prof. Dr., Anadolu Üniversitesi, Açıköğretim Fakültesi, Uzaktan Öğretim Bölümü, vekergil@anadolu.edu.tr

Orcid No: 0000-0002-6790-8529

Bu makaleye atıfta bulunmak için: Savaş, A.B., \& Ekergil, V. (2019). Üniversitelerin Sağlık Yönetimi Programlarında Muhasebe ve Finans Derslerinin Yeri ve Türkiye Uygulaması. Alanya Akademik Bakış, 3(2), 123-150.

\section{Anahtar kelimeler:}

Sağllk Yönetimi

Programlarl,

Muhasebe-Finans,

Yükseköğretim

Kurumlart

Makale Geliş Tarihi:

08.04.2019

Kabul Tarihi:

24.04.2019

Keywords:

Organizational

Culture

Organizational

Justice

Knowledge Sharing

\section{ÖZET}

Bu araştırma, sağllk yönetimi programlarında yükseköğretim kurumlarının ders müfredatlarında hangi muhasebe ve finans derslerine yer verildiğ $i$ ve bu derslerin yeterliliğinin tespit edilmesi amacıyla yapılmıştır. Araştırmada, 189'u Türkiye, 12'si Kuzey Kıbrıs Türk Cumhuriyeti (KKTC) olmak üzere toplamda 201 üniversite ele alınmıstır. Muhasebe derslerine yeterince önem verilse de muhasebenin önemli bir aracı olan "Finansal (Mali) Tablolar Analizi" ile "Yönetim Muhasebesi" derslerine fazla önem verilmediği belirlenmiştir. Să̆llk yönetimi ders müfredatlarında yer alan "muhasebe" ve "finans" ders yelpazesinin geniş tutulması gerektiği sonucuna ulaşılmış̧ır.

\section{ABSTRACT}

The aim of this study was to determine which accounting and finance courses are included in the curriculum of higher education institutions in health management programs and to determine the adequacy of these courses. In this study, there are a total of 201 universities, 189 of which are in Turkey and 12 of them are in Turkish Republic of Northern Cyprus (TRNC). Although accounting lessons were given importance, it was determined that "financial statements analysis" and "management accounting" courses, which are an important tool of accounting, were not given much importance. It has been determined that the "accounting " and "finance" courses in the health management course curriculum should be kept broad. 


\section{GİRIŞ}

Geçmişten günümüze kadar yaşanılan süreçte, hastanelerin büyük ve karmaşık organizasyonlar haline gelmesi, teknolojinin gelişimi, sağlık hizmeti finansmanının karmaşıklığı ve sağlık hizmeti sunumunda hükümetlerin büyük roller üstlenmesi gibi çarpıcı değişiklikler, sağlık kurumlarının verimli ve etkin bir şekilde yönetilmesini zorunlu hale getirmiştir. Günümüzde sağlık yöneticilerinin sağlık yönetimi alanındaki temel rolleri; insan kaynakları yönetimi, finansal yönetim, maliyet muhasebesi, stratejik planlama ve karar alma, pazarlama vb. biçimde sıralanmaktadır. Sağlık yönetiminin temel amacı, sağlık hizmetlerinin koordineli biçimde verilmesinin ve sağlık kuruluşunun etkin bir biçimde yönetilmesinin sağlanmasıdır. Yöneticilerin; insan kaynakları ve mali kaynakların yönetimine ilişkin mevzuata hâkim olmaları, bilim ve diğer dinamikleri birleştiren disiplinler arası alanlarda da eğitim almaları gerekmektedir (healtcareadministrationedu.org). Nitekim 22 Mayıs 2014 tarih ve 29007 sayılı Resmî Gazetede yayımlanan "Sağlık Meslek Mensupları ve Sağlık Hizmetlerinde Çalışan Diğer Meslek Mensuplarının İş ve Görev Tanımlarına Dair Yönetmelik"in "EK-2" kısmındaki bentlerde sağlık yöneticisinin muhasebe ve finansla ilgili görev ve sorumlulukları şöyle sıralanmaktadır:

c) Kurumun muhasebe, bütçe, mali analiz ve maliyet analizi faaliyetlerini yürütür.

ç) Sağlık hizmetleri sunumunun planlanması, yürütülmesi ve sonuçlarının değerlendirilmesi sürecinde görev alır.

d) Kurumda tıbbi ve hasta bakımı dışında verilen hizmetlerin organizasyonu, yürütülmesi ve denetimini sağlar.

Yasanın sağlık yöneticilerine yüklediği bu sorumluluklar çeşitli alanlarda uzmanlıklarını birleştirmelerini gerekli kılmaya zorlamaktadır. Bu yöneticilerin; kurumun finansal yönetim politikalarını belirlemesi, uygulaması ve yönetmesi, muhasebe, bütçe, finansal analiz ve maliyet analizi faaliyetlerini yürütmesi, sağlık hizmetlerini planlaması, yürütmesi ve sonuçlarını değerlendirmesi gibi işletmenin bugününü ve geleceğini en etkin bir şekilde yönetmesi gerekmektedir.

Finkler ve Ward'a göre (Finkler and Ward, 2006: 1-3) bu karmaşık yapı, muhasebe ve finansal yönetimi zorunlu hale getirerek, sağlık kuruluşu içerisinde bulunan tüm alanlara yayılmasına neden olmaktadır. Sağlık yöneticilerinin tümünün, sağlık hizmeti sunulan organizasyon içerisinde hangi alana yöneldiklerine bakılmaksızın sağlam bir muhasebe ve finansal yönetim deneyimine sahip olması gerekmektedir.

Walshe ve Smith'e göre (Walshe and Smith, 2006: 1) sağl1k sisteminde, geleceğin sağlık yöneticileri; teori ve pratiği birleştirebilmeli, yöneticilik ve liderlik niteliklerinin özünde bulunan esneklik ve uyuma sahip olmalıdır.

Bugün Türkiye'deki hastanelerin en temel sorunu, yeterli bütçeye sahip olamamaktır. Hastaneler ihtiyaç duydukları harcamaları yapabilecek ve bu harcamalara kaynak oluşturabilecek geliri yaratabilecek, nitelikli yöneticilere ihtiyaç duymaktadır. Yöneticinin işletmeyi sürdürülebilir kılma mücadelesinde karar seçeneklerine ulaşması ve bunların arasında doğru olanını seçme yeterliliğine sahip olması gerekmektedir. $\mathrm{Bu}$ nitelikte yöneticilerde ise muhasebe ve finans bilgisinin üst düzeyde olması gerekmektedir. 
Sağlık yöneticilerinin gerekli nitelikte yetiştirilebilmesi için üniversitelerde sağlık yönetimi programlarında "muhasebe ve finans" derslerine gerekli önem verilmelidir.

Finkler ve Ward (Finkler and Ward, 2006: 3) sağlik hizmeti sunulan organizasyon içerisinde, sağlık yöneticilerinin hangi alana yöneldiklerine bakılmaksızın sağlam bir muhasebe ve finansal yönetim deneyimine sahip olması gerektiğini ifade etmektedir. Türkiye'de sağlık yönetimi eğitimi ilk kez 1963 yılında Sağlık Bakanlığı'na bağlı olarak kurulan Sağlık İdaresi Yüksek Okulu (S.İ.Y.O.) bünyesinde başlamıştır. 2019 yılına gelindiğinde ise, bu sayı lisans düzeyinde 63 fakülteye ve 13 yüksekokula ulaşılmıştır. Sağlık yönetimi programlarından mezun olan öğrencilerin, mesleğini yürütebilecek yeterlilikte uzmanlığına sahip olup olmadığı ise tartışma konusudur.

\section{LITERATÜR}

Dünya Sağlık Örgütü'nün Dünya Sağlık Raporu'nda (WHO, 2000: 5) sağlık sisteminin ne olduğunun, nelerden oluştuğunun ve nerede başlayıp nerede biteceğinin tam olarak ifade edebilmenin oldukça zor olduğu belirtilmektedir. Sağlık sistemi; toplum sağlı̆̆ının geliştirilmesi, iyileştirilmesi ve sürdürülebilir olmasına yönelik üç temel amacı sağlayabilmek adına yapılacak tüm faaliyetleri kapsamaktadır. Sağlığın geliştirilmesi ve hastalıkların önlenmesi gibi geleneksel halk sağlığı faaliyetleri ile bu amaca ulaşmak için başvurulması gereken yöntemler, sağlı̆̆ın geliştirilmesine yönelik yol ve çevre güvenliğinin iyileştirilmesi vb. diğer müdahaleler de sağlık sisteminin birer parçası olmaktadır.

Bir işletmenin temel amacı kaliteli ve ucuz ürün ya da hizmet üretimi olurken, sağlık kurumları yönetiminin temel amacı toplum sağlığının korunması ve hastaların yaşam kalitesinin yüksek tutulmasının sağlanmasıdır (Kaptanoğlu, 2011: 86).

Ayanoğlu ve diğerleri (Ayanoğlu vd. 2013), Türkiye'deki üniversitelerin sağlık yönetimi eğitiminde muhasebe ve finans dersleri "lisans düzeyinde" ele almaktadır. Üniversitelerde 2000-2012 yılları arasındaki gelişmelerin 2000, 2006, 2009 ve 2012 yılları temel alınarak incelenmektedir. Çalışmada muhasebe ve finans derslerinin lisans eğitiminde farklı sınıflarda ve farklı isimlerde yer aldığı, bu derslerin bölümlerin bütün dersleri içerisinde ortalama olarak $\% 9,5$ 'luk bir paya sahip olduğu ifade edilmektedir.

Çil Koçyiğit ve diğerleri (Çil Koçyiğit vd. 2016) Ankara Üniversitesi ve Gazi Üniversitesi Sağl1k Yönetimi Bölümü’nde "lisans" eğitimi gören öğrencilerin muhasebe derslerindeki başarılarını etkileyen faktörlerle ilgili görüşleri belirlemeyi amaçlamışlardır. Bu çalışmada; muhasebe derslerini sevmelerinin ve muhasebe derslerine ilgi duymalarının başarıyı artırdığı sonucuna ulaşılmıştır.

Çil Koçyiğit ve diğerleri (Çil Koçyiğit vd. 2018), sağlık yönetimi eğitiminde muhasebe ve finans derslerini "yüksek lisans" düzeyinde ele almışlardır. Çalışmada; 2017 yılı itibariyle sağlık yönetimi alanında yüksek lisans eğitimi veren üniversiteler incelenmiştir. Sağlık yönetimi yüksek lisans programlarının çoğunda muhasebe ve finans dersleri yer almakta ve bu derslerin toplam kredi içerisindeki ortalaması \%16,5 ile \%20 arasındadır. Bu derslerin çoğunlukla (\%67 - \%86 arası) seçmeli ders olarak okutulduğu görülmektedir.

Biçer ve diğerleri (Biçer vd. 2018) tarafından yapılan çalışmanın amacı, Cumhuriyet Üniversitesi Sağlık Yönetimi bölümünde lisans eğitimini sürdürmekte olan öğrencilerin muhasebe dersine karşı tutumlarını saptamak ve tutumlarının başarı düzeylerine etkisini belirlemektir. Tanımlayıcı araştırmada elektronik anket yöntemi kullanılmıştır. Araştırma 
sonucunda, ankete katılan öğrencilerin muhasebe dersinin gerekliliğinin kısmen farkında oldukları ve bölümü seven öğrencilerin derse karşı olumlu tutum sergiledikleri görülmüştür. Aynı zamanda derse olan tutumlarının başarı düzeylerini etkilediği saptanmıştır.

Özsarı ve Söylet'e göre (Özsarı ve Söylet, 2013) sağlık eğitimi, ön lisans, lisans, yüksek lisans ve doktora olarak yapılandırılmalıdır. Ön lisans eğitimi; yöneticiden çok, yönetim sürecinde görev alacak becerisi yüksek çalışanlar yetiştirmeyi amaçlamalıdır. Bu nedenle ön lisans eğitimi; sağlık hizmetlerinde muhasebe, pazarlama ve lojistik gibi uzmanlık alanlarında verilmelidir.

Kahyaoğlu ve diğerleri (Kahyaoğlu vd. 2013), yöneticilerin, sağlık yönetimi ve eğitimi ile ilgili değerlendirmelerine ilişkin bulgular üzerinde durmuştur. Yöneticilerin \%89,5'inin kamu sağlık kuruluşlarında yönetici olarak görev alacak kişilere sağlık yönetimi eğitiminin zorunlu olarak verilmesi gerektiğini, sağl1k kurumlarında görev yapan sağlık yönetimi alanında eğitim almış yöneticilerin insan kaynakları yönetimi $(\% 53,5)$, finansal yönetim $(\% 51,2)$ ve muhasebe $(\% 34,9)$ alanlarında eksiklikleri olduğunu belirtmişlerdir.

Yine yöneticilerin gelecekte sağlık yönetiminde yaklaşık \%71 oranında bilgi teknolojileri, $\% 65$ sağlık hukuku, \%64 kalite-akreditasyon, \%59,3 finansman, \%55,8 sağlık ekonomisi ve \%53,5 sağlı politikası ve planlamasının önem kazanacağının düşünüldüğü tespit edilmiştir.

"Etkili bir sağlık yönetimi eğitimi programının oluşturulması sizce hizmeti nasıl etkileyebilir?" sorusuna \%89,5 oranında "Kaynaklar verimli kullanılır" ve \%39,5 oranında "Finansman sorunları ortadan kalkar" yanıtları alınmıştır.

Dalkılıç’a göre (Dalkılıç 2015), ön lisans düzeyinde sağlık kurumları işletmeciliği eğitiminde muhasebe dersi genellikle "sağlık hizmetlerinde muhasebe" adıyla verilmektedir. Türkiye'de sağlık yönetimi eğitim müfredatına bakıldığında üniversitelerin eğitim programlarının tam anlamıyla aynı olmadığı ortaya çıkmaktadır. Muhasebe, Maliyet Muhasebesi ve Finansal Yönetim derslerine genel olarak rastlanılmamaktadır.

Çimen'in de (Çimen, 2010) belirttiği gibi; sağllk hizmetlerinin yönetimi, insan sağllğ konusunda olduğu kadar, sosyoloji, psikoloji, iletişim, insan kaynakları, işletme, muhasebe, hukuk, ekonomi gibi alanlarda da bilgi ve beceriye sahibi olmayı gerektirmektedir.

Literatürde incelenen kaynaklara bakıldığında, sağlık yönetimi lisans programlarında yer verilen muhasebe ve finans dersleri bağlamında; derslerin gerek AKTS kredileri gerek içerikleri ve gerekse hangi derslere önem verilmesi gerektiğini ortaya koyan bilimsel bir çalışmaya rastlanılmamıştır.

Amerika Birleşik Devletleri’nde Sağlık Yönetimi alanında lisans düzeyinde eğitim verilen ve müfredatlarına ulaşılabilen 8 program (Alabama, J. Madison, Massachusetts, Newbury, Rider, Ruthgers, Southern Illinois ve Springfield Üniversiteleri) incelendiğinde, yapılan çalışmaya ilişkin bir takım önemli bulgular elde edilmiştir. Örneğin bir öğrencinin mezun olabilmesi için; ortalama 119 kredilik ders alması gerektiği (en alt 103, en üst 124 kredi), muhasebe ve finans derslerinin bölüm başına düşen ortalama kredisinin ise 9,38 kredi olduğu (8 programda, toplamda 75 kredilik muhasebe ve finans dersi bulunmaktadır) görülmektedir.

Bu çalışmada, 2014-2018 yılları arasında Türkiye'de lisans düzeyinde eğitim verilen sağlık yönetimi programları ile bu programların müfredatlarında yer alan tüm dersler incelenmiştir. 
Yapılan inceleme sonucunda;

a) Muhasebe ve finans derslerinin ders kredileri ve AKTS kredileri,

b) Sinıflara göre, derslerin zorunlu ya da seçmeli ders statüsünde bulunma durumları,

c) Derslerde işlenen konu dağılımları ile konuların yer alma oranlarına (\%) göre ders içeriklerinin benzerlik durumları,

d) Hangi derslere yeterince önem verilmediği,

e) Dünyada yaşanan gelişmelere paralel olarak ders müfredatlarında hangi derslerin yer almadığı üzerinde durularak, derslerin yeterli olup olmadıklarının tespit edilmesi amaçlanmıştır.

\section{YÖNTEM}

Yöntem bölümünde; araştırmanın modeli, amacı, kapsamı, süreci ve metodolojisi hakkında bilgi verilecektir.

\subsection{Araştırmanın Modeli}

Üniversitelerin sağlık yönetimi programlarında yer alan muhasebe ve finans derslerinin yerinin incelenmesini amaçlayan bu araştırma nicel araştırma yöntemi temel alınarak desenlenmiştir.

\subsection{Araştırmanın Amacı ve Önemi}

Sağlık yönetiminde muhasebe ve finansın önemi bağlamında; sağlık yöneticilerinin ilgili sağlık kuruluşlarının sürdürülebilirliklerini sağlayabilmeleri amacıyla verecekleri iyileştirici kararlar, eğitimleri süresince alacakları muhasebe ve finans derslerindeki bilgi düzeyleri ile mesleki bilgi ve tecrübelerine bağlı bulunmaktadır. Türkiye'deki birçok üniversitede Sağlık Yönetimi alanında lisans düzeyinde eğitim verilse de, verilen bu eğitimde disiplinler arası alanlarda yer alan muhasebe ve finans derslerinin yeterli düzeyde olup olmadı̆̆ bilinememektedir. $\mathrm{Bu}$ bağlamda, muhasebe ve finans derslerinin yeterli olup olmadı̆̆ üzerinde durulmakta, şayet yeterli değilse, müfredat programlarında hangi derslere ağırlık verilmesi gerektiği, çalışmanın amacını oluşturmaktadır.

\subsection{Araştırmanın Kapsamı}

Araştırmanın kapsamını; Türkiye'de ve Kuzey Kıbrıs Türk Cumhuriyeti’nde sağlık yönetimi alanında, son beş yılda (2014-2018 dahil) lisans düzeyinde eğitim verilen, Sağlık Bilimleri Fakültesi, İktisadi ve İdari Bilimler Fakültesi, İşletme Fakültesi, Açıköğretim Fakültesi ile Sağlık Bilimleri Yüksekokulu ve Sağlık Yüksekokulları oluşturmaktadır.

Türkiye ve Kuzey Kıbrıs Türk Cumhuriyeti’nde (K.K.T.C.) Sağlık Yönetimi alanında lisans düzeyinde eğitim verilen yükseköğretim kurumlarının sayıları; 2014 yılı için 172'si Türkiye, 7'si K.K.T.C. olmak üzere toplamda 179 üniversite, 2018 yılı için ise 189'u Türkiye, 12'si K.K.T.C. olmak üzere toplamda 201 üniversite temel alınarak incelenmişstir.

\subsection{Araştırmanın Yöntemi}

Sağlık Yönetimi alanında lisans düzeyinde eğitim verilen yükseköğretim kurumları, "Ölçme, Seçme ve Yerleştirme Merkezi Başkanlığı (ÖSYM)” tarafından, 2014, 2015, 2016, 2017 ve 
2018 yıllarında yayımlanan "Yükseköğretim Programları ve Kontenjanları Kılavuzu"ndan yararlanılarak elde edilmiştir.

Ders müfredatları, Türkiye'deki ilgili yükseköğretim kurumlarının resmi web sayfalarında yer alan, sağlık yönetimi programlarının muhasebe ve finans alanında verilen dersleri, derslerin kredi değerleri ve 1999 yılında kabul edilen Bologna Kararlarının temel hedeflerinden olan Avrupa Kredi Transfer Sistemi (AKTS) kredilerinin incelenmesi sonucunda oluşturulmuştur.

\section{BULGULAR}

Bulgular bölümünde; araştırmada elde edilen verilerin sonuçları maddeler halinde ele alınarak aşağıda sıralanmıştır.

a) Sağlık bilimleri alanında (Tıp Fakültesi, Diş Hekimliği Fakültesi, Eczacılık Fakültesi ile Fizik Tedavi ve Rehabilitasyon Yüksekokulu dışında) lisans düzeyinde eğitim verilen yükseköğretim programlarının; araştırmanın yapıldığı ilk dönem olan 2014 yılında toplam 132 iken, son dönem olan 2018 yılında yaklaşık \%26'lık bir artışla 166'ya ulaştığı görülmektedir.

b) Sağlık Yönetimi alanında lisans düzeyinde eğitim verilen bölümler; 2014 yılında toplam 48 iken, 2018 yılında yaklaşık \%58'lik bir artışla 76'ya ulaşmış ve dağılımlara Tablo 1'de yer verilmiştir.

Tablo 1. Yükseköğretim Kurumları ile Sağlık Yönetimi Bölümlerinin Dağılımları

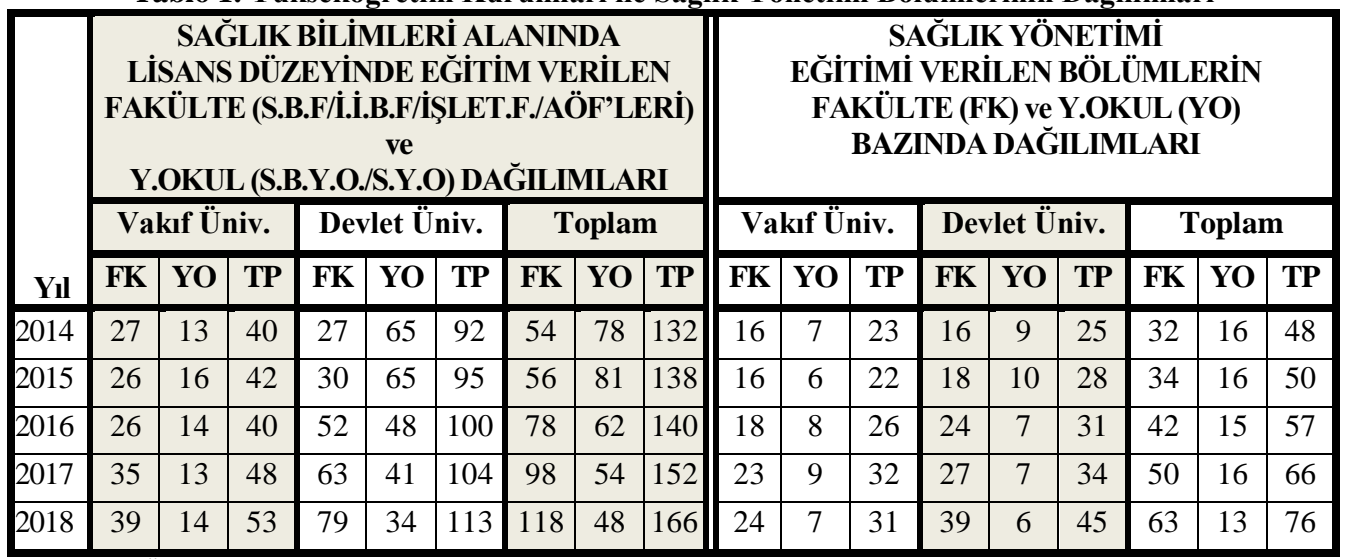

Kaynak: Ölçme, Seçme ve Yerleştirme Merkezi Başkanlığı tarafından ilgili yıllara göre yayımlanan "Yükseköğretim Programları ve Kontenjanları Kılavuzu"ndan yararlanılarak yazarlar tarafından oluşturulmuştur.

(Not: Tabloda yer alan FK=Fakülte'leri, YO=Yüksekokul'larl, TP=Toplam'ı ifade etmektedir.)

c) Tablo 1'de yer verilen, Sağlık Yönetimi Bölümlerinde Eğitim Verilen Fakülte/Yüksekokulların 2014 ve 2015 yıllarının dağılımları, elde edilen diğer verilerle birlikte değerlendirildiğinde, Sağlık Yönetimi alanındaki bölüm adlarının;

- 2014 yılında eğitim verilen 19 bölümün; 12’sinin Sağlık Kurumları Yöneticiliği, 6’sının Sağlık Kurumları İşletmeciliği, 1'inin ise Sağlık İdaresi adı ile yer aldığı, 
- 2015 yılına gelindiğinde, bu programlardan 18'inin adının; Sağlık Yönetimi olarak değiştirildiği,

- Sağlık İdaresi adı ile yer alan 1 bölümde ise 2016 yılından itibaren Sağlık Yönetimi adıyla eğitime devam edildiği görülmektedir.

c) Tablo 1'de yer alan, Sağlık Yönetimi bölümlerinde eğitim verilen Fakülte/Yüksekokulların 2018 yılı itibariyle Sağlık Yönetimi bölüm sayıları şöyledir:

- Vakıf Üniversitelerinde Sağlık Yönetimi ile ilgili bölümlerin sayısı 31'dir. Bunlar;

\begin{tabular}{|l|l|}
\hline 21 Sağlık Bilimleri Fakültesi (SBF), & 1 Uygulamalı Bilimler Fakültesi (UBF), \\
\hline 6 Sağlık Bilimleri Yüksekokulu (SBYO) & 1 Sağlık Yüksekokulu (SY). \\
\hline 2 İktisadi, İdari ve Sosyal Bilimler Fakültesi (İ̈BF), & \multicolumn{2}{|l}{} \\
\cline { 1 - 2 }
\end{tabular}

- Devlet Üniversitelerinde Sağlık Yönetimi ile ilgili bölümlerin sayısı 45’tir. Bunlar ise;

\begin{tabular}{|l|l|}
\hline 26 Sağlık Bilimleri Fakültesi (SBF), & 5 Sağlık Yüksekokulu (SY). \\
\hline 9 İktisadi, İdari ve Sosyal Bilimler Fakültesi (İ̈BF), & 2 İşletme Fakültesi (İF), \\
\hline 1 Uygulamalı Bilimler Fakültesi (UBF), & 2 Açı̈öğretim Fakültesi (AÖF) \\
\hline
\end{tabular}

olmak üzere Türkiye'de toplam 76 programda eğitim verilmektedir.

d) Yine Tablo 1'de yer alan, Sağlık Yönetimi eğitimi verilen bölümlerin Fakülte ve Yüksekokullara göre 2018 yılı dağılımları ile elde edilen diğer veriler birlikte değerlendirildiğinde,

- 2 Vakıf Üniversitesi'nde (1'i KKTC); hem Sağlık Bilimleri Fakültesi'nde hem de Sağlık Bilimleri Yüksekokulu'nda aynı alanda eğitim verildiği,

- 1 Devlet Üniversitesi'nde Sağlık Bilimleri Fakültesi ve Sağlık Yüksekokulu yer almasına rağmen eğitimin; İktisadi ve İdari Bilimler Fakültesi'nde verildiği,

- 1 Devlet Üniversitesi'nde Sağlık Yüksekokulu bulunmasına rağmen eğitimin; Uygulamalı Bilimler Yüksekokulu'nda verildiği,

- 9 Devlet Üniversitesi’nde Sağlık Bilimleri Fakültesi bulunmasına rağmen ilgili alandaki eğitimin; 2 üniversitede İşletme Fakültesi, 6 üniversitede İktisadi ve İdari Bilimler Fakültesi, 1 üniversitede ise Sağlık Yüksekokulu'nda verildiği,

- 1 Vakıf Üniversitesi’nde Sağlık Bilimleri Fakültesi bulunmasına rağmen, ilgili alandaki eğitimin; İktisadi, İdari ve Sosyal Bilimler Fakültesinde verildiği,

- K.K.T.C.'nde, 2 üniversitede Sağlık Bilimleri Fakültesi bulunmasına rağmen, Sağlık Yönetimi eğitiminin; 1 üniversitenin Sağlık Yüksekokulu'nda, diğer üniversitenin ise Sağlık Bilimleri Yüksekokulu'nda verildiği görülmektedir.

e) Sağlı Yönetimi alanında lisans düzeyinde eğitim verilen 76 bölümün müfredatı incelenerek, mezuniyet için gerekli olan toplam kredi miktarı ile AKTS kredilerinin dağılımlarına Tablo 2'de yer verilmiştir. Bilgilerine ulaşılamayan yükseköğretim kurumları ile elde edilemeyen bilgilere ilişkin alanlar, tabloda koyu renkle işaretlenmiş bulunmaktadır. 
Tablo 2. Sağlık Yönetimi Bölümlerinin Kredi Dağılımları

\begin{tabular}{|c|c|c|c|c|c|}
\hline Üniversite & Kredi * & AKTS & Üniversite & Kredi * & AKTS \\
\hline Acıbadem & 192,5 & 242 & İst. Ü. Cerrahpaşa & 192 & 247 \\
\hline Afyon Sağlık Bil. & 201 & 240 & İst.Yeni Yüzyıl & 173 & 252 \\
\hline Aksaray & 238 & 240 & İstinye & 162 & 240 \\
\hline Altınbaş & & & İzmir Bakırçay & & \\
\hline Anadolu (AÖF) & 158 & 240 & İzmir Ekonomi & 135 & 240 \\
\hline Ankara Hacı Bayram Veli & 130 & 240 & İzmir Katip Çelebi & 206 & 231 \\
\hline Ankara & 172 & 240 & Khrmrş. Sütçü İmm & 162 & 240 \\
\hline Ankara Yıldırım Beyazıt & 115,5 & 240 & Karadeniz Teknik & 161,5 & 240 \\
\hline Ardahan & 160 & 240 & Krmn. Mehmet B. & 127 & 240 \\
\hline Atatürk (AÖF) & 149 & 240 & Kirıkkale & 175 & 240 \\
\hline Avrasya & 144 & 240 & Kırklareli & 162 & 240 \\
\hline Bahçeşehir & 130 & 240 & Kilis 7 Aralık & 179,5 & \\
\hline Bandırma 17 Eylül & 179 & 238 & Marmara & 240 & 240 \\
\hline Başkent & 169 & 240 & Mersin & 162 & 255 \\
\hline Bayburt & 190 & 240 & Muğla Sitk1 Koçman & 148 & 240 \\
\hline Beykent & 111 & 240 & Muş Alparslan & 151 & 240 \\
\hline Bezm-i Alem & 170 & 240 & Necmettin Erbakan & 154 & 240 \\
\hline Biruni & 166 & 241 & Nişantaşı & 128 & 222 \\
\hline Burdur Mehmet A. & 162 & 240 & Ondokuz Mayıs & 141 & 81 \\
\hline Çanakkale 18 Mart & & & Sağlık Bilimleri Gülhane & & \\
\hline Dicle & 143 & 240 & Sağlık Bilimleri & 182 & 242 \\
\hline Düzce & 159 & 240 & Sakarya & 111 & 240 \\
\hline Erzinc. B.Yıldırım & 65 & 240 & Selçuk & 152 & 264 \\
\hline Eskişehir OGÜ & 165 & 240 & Sivas Cumhuriyet & 152 & 224 \\
\hline Gümüşhane & 151 & 240 & Süleyman Demirel & 158,5 & 235 \\
\hline Hacettepe & 156 & 240 & Tokat GOP & 174 & 237 \\
\hline Hitit & 152 & 240 & Toros & 165 & 240 \\
\hline İstanbul Arel & 155 & 240 & Trakya & 208 & 244 \\
\hline İstanbul Aydın & 173 & 240 & Uşak & 151 & 240 \\
\hline İstanbul Bilgi & 182 & 240 & Üsküdar & 165 & 240 \\
\hline İstanbul D. Bilim & & & Yozgat Bozok & & \\
\hline İstanbul Gelişim & 136 & 240 & Yüksek İhtisas & & \\
\hline İstanbul Kent & 142 & 240 & Doğu Akdeniz & 127 & \\
\hline İstanbul Medeniyet & 165 & 240 & Girne Amerikan & 155 & 219 \\
\hline İstanbul Medipol (Fak.) & 154 & 240 & Lefke Avrupa (Fak) & & \\
\hline İstanbul Medipol (Y.O) & 154 & 240 & Lefke Avrupa (YO) & & \\
\hline İstanbul Okan & 129 & 240 & Uluslararas1 Kibris & 124 & \\
\hline İstanbul Sabahattin Zaim & 155,5 & 240 & Yakın Doğu & 158 & 240 \\
\hline
\end{tabular}

Kaynak: İlgili yükseköğretim kurumlarının "Kaynakça" da belirtilen resmî web sitelerinden yararlanılarak yazarlar tarafindan oluşturulmuştur.

(*) Seçmeli derslerin bulunması nedeniyle, mezuniyet için gerekli olan toplam AKTS kredisine ulaşılana kadar, seçilecek derse bağlı olarak toplam kredilerde değişiklikler söz konusu olabilir.

Seçmeli ders kategorisinde kaç dersin alınacağı net olarak açıklanmayan bölümlerin, toplam ders kredilerinde değişiklikler söz konusu olabilir.

Ders kredileri belli olmayan bölümler için yapılan hesaplamalarda; her 1 saatlik teorik ders ile laboratuvar dersi: 1 kredi, her 1 saatlik uygulama dersi ise: 0,5 kredi üzerinden hesaplanmıştır. $\mathrm{Bu}$ 
nedenle, ilgili yükseköğretim kurumlarında geçerli olan gerçek toplam krediler arasında uyumsuzluk söz konusu olabilir.

f) Tablo 2'de yer alan dağılımlara bakıldığında;

- 76 bölümün, 9'unda ders kredilerinin, 12'sinde ise AKTS kredilerinin resmi internet sitelerinde yer almadı̆̆

- Ders kredilerine ulaşılan 67 bölümde bir öğrencinin mezun olabilmesi için alması gereken toplam ders kredisi, ortalamada yaklaşık 158 kredi olarak hesaplanmakta ve yaklaşık olarak \%42 oranındaki 28 bölümün ders kredileri 150-165 aralığında yer almaktadır.

- AKTS kredilerine ulaşılan 64 bölümde ise bir öğrencinin mezun olabilmesi için alması gereken toplam AKTS kredisi, ortalamada yaklaşı 237 AKTS olarak hesaplanmakta ve yaklaşık olarak \%75 oranındaki 48 bölümün AKTS kredisinin 240 olduğu görülmektedir.

g) Sağlık Yönetimi alanında, lisans düzeyinde eğitim verilen bölümlerin ders müfredatlarında yer alan, muhasebe ve finans derslerinin dağılımları Tablo 3'te yer almaktadır

h) Sağlık Yönetimi alanında, lisans düzeyinde eğitim verilen bölümlerin müfredatlarında yer alan (Tablo 3) dersler ve elde edilen diğer veriler birlikte değerlendirildiğinde;

- Henüz 1. ve 2. sinıf düzeyinde eğitime devam edilen 9 bölümde, derslerin ilgili kurumların web sayfalarında yer almadığı ya da ulaşılamadığı,

- 21 Bölümde henüz 1. ve 2. sınıf düzeyinde eğitime devam ediliyor olsa da, her dört yılın derslerine yer verildiği ya da ulaşılabildiği görülmektedir.

i) Sağlık Yönetimi alanında, lisans düzeyinde eğitim verilen 76 bölümün, müfredatlarına erişilebilen 64 bölümünde, alanlarına göre bölümlendirilen derslere ilişkin bulgular Tablo 3 'te yer almaktadir.

Tablo 3. Muhasebe ve Finans Derslerinin Dağılımları

\begin{tabular}{|c|c|c|c|c|c|c|c|c|c|c|c|c|c|c|c|c|c|c|c|c|}
\hline \multirow[b]{3}{*}{ Üniversite } & \multicolumn{4}{|c|}{ 1. GRUP } & \multicolumn{4}{|c|}{ 2. GRUP } & \multicolumn{4}{|c|}{ 3. GRUP } & \multicolumn{4}{|c|}{ 4. GRUP } & \multicolumn{4}{|c|}{ 5. GRUP } \\
\hline & \multicolumn{4}{|c|}{$\begin{array}{c}\text { Muhasebe / } \\
\text { Genel } \\
\text { Muhasebe/ } \\
\text { Muhasebe } \\
\text { Illkeleri }\end{array}$} & \multicolumn{4}{|c|}{$\begin{array}{c}\text { Maliyet } \\
\text { Muhasebesi/ } \\
\text { Maliyet Yönetimi }\end{array}$} & \multicolumn{4}{|c|}{$\begin{array}{c}\text { Yönetim } \\
\text { Muhasebesi }\end{array}$} & \multicolumn{4}{|c|}{$\begin{array}{c}\text { Finans Yönetimi/ } \\
\text { Finansal } \\
\text { Yönetim } \\
\end{array}$} & \multicolumn{4}{|c|}{$\begin{array}{c}\text { Mali Tablolar } \\
\text { Analizi/ } \\
\text { Finansal } \\
\text { Tablolar } \\
\text { Analizi/ } \\
\text { Mali Analiz } \\
\text { Yöntemleri } \\
\end{array}$} \\
\hline & क्ञ & $\frac{n}{N}$ & : & 党 & 音 & $\frac{2}{N}$ & : & 告 & 馬 & $\frac{n}{N}$ & : & $\frac{5}{4}$ & 馬 & $\frac{n}{N}$ & : & $\frac{n}{4}$ & 馬 & $\frac{n}{N}$ & : & $\frac{5}{2}$ \\
\hline Acrbadem & 1 & $\mathrm{Z}$ & 6 & 10 & 2 & $\mathrm{Z}$ & 3 & 5 & 2 & $\mathrm{Z}$ & 3 & 5 & 3 & $\mathrm{Z}$ & 6 & 10 & & & & \\
\hline Afyon Sağ.Bil & 1 & $\mathrm{Z}$ & 4 & 11 & & $\mathrm{Z}$ & 3 & 5 & & & & & 3 & $\mathrm{Z}$ & 6 & 8 & & & & \\
\hline Aksar & 1 & $\mathrm{Z}$ & 6 & 7 & & $\mathrm{Z}$ & 3 & 4 & & & & & 3 & $\mathrm{Z}$ & 6 & 10 & & & & \\
\hline Anadolu-AÖF & 1 & $\mathrm{Z}$ & 6 & 10 & & $\mathrm{Z}$ & 3 & 6 & & & & & 4 & $\mathrm{Z}$ & 3 & 4 & & & & \\
\hline Ank. H.Bayr. & 1 & $\mathrm{Z}$ & 6 & 10 & 2 & $\mathrm{Z}$ & 3 & 6 & 4 & $\mathrm{~S}$ & 3 & 5 & 3 & $\mathrm{Z}$ & 3 & 7 & 3 & $\mathrm{~S}$ & 3 & 5 \\
\hline Ankara & 1 & $\mathrm{Z}$ & 6 & 9 & 2 & $\mathrm{Z}$ & 3 & 5 & & & & & 3 & $\mathrm{Z}$ & 4 & 7 & & & & \\
\hline A.Y1ld.Bey & 1 & $\mathrm{Z}$ & 4 & 8 & 3 & $\mathrm{Z}$ & 2 & 5 & & & & & 4 & $\mathrm{Z}$ & 4 & 10 & & & & \\
\hline Ardahan & 1 & $\mathrm{Z}$ & 4 & 8 & 2 & $\mathrm{Z}$ & 3 & 4 & & & & & 3 & $\mathrm{Z}$ & 4 & 8 & & & & \\
\hline
\end{tabular}




\begin{tabular}{|c|c|c|c|c|c|c|c|c|c|c|c|c|c|c|c|c|c|c|c|c|}
\hline Atatürk- AÖF & 1 & $\mathrm{Z}$ & 3 & 5 & 2 & $\mathrm{Z}$ & 3 & 5 & & & & & 2 & $\mathrm{Z}$ & 3 & 5 & & & & \\
\hline Avrasya & 1 & Z & 8 & 10 & & & & & & & & & 3 & $\mathrm{Z}$ & 8 & 10 & & & & \\
\hline Bahçeşehir & 1 & $\mathrm{Z}$ & 4 & 9 & & & & & & & & & 3 & $\mathrm{Z}$ & 2 & 4 & & & & \\
\hline Band. 17 Eylül & 1 & $\mathrm{Z}$ & 6 & 10 & 3 & $\mathrm{Z}$ & 3 & 5 & 4 & $\mathrm{~S}$ & 3 & 4 & 3 & $\mathrm{Z}$ & 3 & 5 & & & & \\
\hline Başkent & 2 & $\mathrm{Z}$ & 6 & 10 & 3,4 & $\mathrm{~S}$ & 3 & 5 & 3,4 & $\mathrm{~S}$ & 3 & 5 & 3 & $\mathrm{Z}$ & 6 & 10 & 4 & $\mathrm{~S}$ & & 5 \\
\hline Bayburt & 1 & $\mathrm{Z}$ & 6 & 8 & 3 & $\mathrm{Z}$ & 6 & 8 & 2 & $\mathrm{Z}$ & 3 & 4 & 3 & $\mathrm{Z}$ & 6 & 8 & 4 & $\mathrm{~S}$ & 3 & 3 \\
\hline Beykent & 1 & $\mathrm{Z}$ & 3 & 5 & 2 & $\mathrm{Z}$ & 3 & 6 & & & & & & & & & 3 & $\mathrm{Z}$ & 3 & 6 \\
\hline Bezm-i Alem & 1 & $\mathrm{Z}$ & 4 & 6 & 2 & $\mathrm{Z}$ & 2 & 3 & 4 & $\mathrm{~S}$ & 2 & 3 & 2 & $\mathrm{Z}$ & 4 & 5 & 3 & $\mathrm{Z}$ & 2 & 3 \\
\hline Biruni & 1 & $\mathrm{Z}$ & 5 & 7 & 2 & $\mathrm{Z}$ & 3 & 4 & & & & & 2 & $\mathrm{Z}$ & 6 & 8 & & & & \\
\hline Burd.M.A.Ers. & 1 & $\mathrm{Z}$ & 6 & 10 & 3 & $\mathrm{Z}$ & 6 & 10 & & & & & 3 & $\mathrm{Z}$ & 3 & 5 & 2 & $\mathrm{Z}$ & 3 & 5 \\
\hline Dicle & 1 & $\mathrm{Z}$ & 6 & 10 & & & & & & & & & 2 & $\mathrm{Z}$ & 3 & 4 & 3 & $\mathrm{~S}$ & 3 & 4 \\
\hline Düzce & 1 & $\mathrm{Z}$ & 6 & 10 & 2 & $\mathrm{Z}$ & 3 & 5 & 4 & $\mathrm{~S}$ & 3 & 4 & 3 & $\mathrm{Z}$ & 3 & 6 & 2 & $\mathrm{~S}$ & 3 & 4 \\
\hline Erz.B.Yıldırım & 1 & $\mathrm{Z}$ & 6 & 12 & 3 & $\mathrm{~S}$ & 3 & 0 & 3 & $\mathrm{Z}$ & 3 & 4 & 2 & $\mathrm{Z}$ & 6 & 8 & 2 & $S$ & 0 & 3 \\
\hline Esk. O.Gazi & 2 & $\mathrm{Z}$ & 6 & 10 & 3 & $\mathrm{Z}$ & 3 & 6 & & & & & 3 & $\mathrm{Z}$ & 6 & 10 & 4 & S & 3 & 4 \\
\hline Gümüşhane & 1 & $\mathrm{Z}$ & 4 & 7 & 2 & $\mathrm{Z}$ & 3 & 6 & & & & & 3 & $\mathrm{Z}$ & 4 & 5 & 4 & $\mathrm{~S}$ & 2 & 4 \\
\hline Hacettepe & 1 & $\mathrm{Z}$ & 6 & 10 & 3 & $\mathrm{Z}$ & 3 & 5 & & & & & 3 & $\mathrm{Z}$ & 6 & 10 & & & & \\
\hline Hitit & 1 & $\mathrm{Z}$ & 6 & 12 & 2 & $\mathrm{Z}$ & 3 & 6 & & & & & 3 & $\mathrm{Z}$ & 3 & 5 & & & & \\
\hline İst. Arel & & & & & 2 & $\mathrm{Z}$ & 3 & 5 & & & & & 2 & $\mathrm{Z}$ & 6 & 10 & & & & \\
\hline İst. Aydın & & & & & 2 & $\mathrm{Z}$ & 3 & 5 & & & & & 3 & $\mathrm{Z}$ & 3 & 5 & & & & \\
\hline İst. Bilgi & 1 & $\mathrm{Z}$ & 6 & 8 & & & & & & & & & 3 & $\mathrm{Z}$ & 3 & 5 & & & & \\
\hline İst. Gelişim & 1 & $\mathrm{Z}$ & 3 & 6 & 2 & $\mathrm{Z}$ & 3 & 3 & & & & & 3 & $\mathrm{Z}$ & 6 & 10 & 2 & $\mathrm{Z}$ & 3 & 5 \\
\hline İst. Kent & 1 & $\mathrm{Z}$ & 3 & 5 & 2 & $\mathrm{Z}$ & 3 & 5 & & & & & 3 & $\mathrm{Z}$ & 6 & 8 & 4 & $\mathrm{~S}$ & 3 & 4 \\
\hline İs. Medeniyet & 1 & $\mathrm{Z}$ & 3 & 5 & 3 & $\mathrm{Z}$ & 3 & 5 & & & & & 3 & $\mathrm{Z}$ & 6 & 10 & & & & \\
\hline İ.Medipol Fak. & 1 & $\mathrm{Z}$ & 2 & 3 & 2 & $\mathrm{Z}$ & 2 & 4 & 3 & $\mathrm{~S}$ & 2 & 3 & 3 & $\mathrm{Z}$ & 3 & 5 & & & & \\
\hline İ.Medipol YO. & 1 & $\mathrm{Z}$ & 2 & 3 & 2 & $\mathrm{Z}$ & 2 & 4 & 3 & $\mathrm{~S}$ & 2 & 3 & 3 & $\mathrm{Z}$ & 3 & 5 & & & & \\
\hline İ. Okan & 1 & $\mathrm{Z}$ & 3 & 6 & & & & & & & & & & & & & & & & \\
\hline İst S. Zaim & 2 & $\mathrm{Z}$ & 3 & 4 & 2 & $\mathrm{Z}$ & 3 & 5 & & & & & 3 & $\mathrm{Z}$ & 3 & 5 & & & & \\
\hline İst. Ü.Cerrahp. & 1 & $\mathrm{Z}$ & 6 & 9 & 2 & $\mathrm{Z}$ & 6 & 10 & & & & & 2 & $\mathrm{Z}$ & 6 & 10 & & & & \\
\hline İst. Y.Yüzy1l & & & & & 2 & $\mathrm{Z}$ & 3 & 4 & & & & & 1 & $\mathrm{Z}$ & 6 & 10 & & & & \\
\hline İstinye & 2 & $\mathrm{Z}$ & 3 & 3 & 3 & $\mathrm{Z}$ & 3 & 4 & & & & & 3 & $\mathrm{Z}$ & 3 & 5 & & & & \\
\hline İzm. Ekonomi & 3 & $\mathrm{Z}$ & 3 & 5 & & & & & & & & & 3 & $\mathrm{Z}$ & 3 & 6 & & & & \\
\hline İzm.K.Çelebi & 2 & $\mathrm{Z}$ & 6 & 10 & & & & & & & & & 2 & $\mathrm{Z}$ & 3 & 5 & & & & \\
\hline K.M. S.İmam & 1 & $\mathrm{Z}$ & 3 & 4 & 2 & $\mathrm{Z}$ & 3 & 4 & 3 & $\mathrm{~S}$ & 3 & 4 & 2 & $\mathrm{Z}$ & 3 & 4 & 3 & $\mathrm{~S}$ & 3 & 4 \\
\hline Kard. Teknik & 2 & $\mathrm{Z}$ & 6 & 8 & 3 & $\mathrm{Z}$ & 3 & 4 & & & & & 4 & $\mathrm{Z}$ & 6 & 10 & 4 & S & 2 & 4 \\
\hline Karam. M.Bey & 1 & $\mathrm{Z}$ & 6 & 12 & & & & & & & & & 3 & $\mathrm{Z}$ & 3 & 7 & & & & \\
\hline Kırıkkale & 1 & $\mathrm{Z}$ & 6 & 12 & 3 & $\mathrm{Z}$ & 6 & 13 & & & & & 3 & $\mathrm{Z}$ & 6 & 12 & & & & \\
\hline Kirklareli & 1 & $\mathrm{Z}$ & 3 & 6 & 3 & $\mathrm{Z}$ & 4 & 6 & & & & & 3 & $\mathrm{Z}$ & 6 & 10 & & & & \\
\hline Kilis 7 Aralık & 1 & $\mathrm{Z}$ & 6 & 7 & 3 & $\mathrm{Z}$ & 3 & 5 & & & & & 2 & $\mathrm{Z}$ & 6 & 9 & 3 & $\mathrm{Z}$ & 3 & 3 \\
\hline Marmara & 1 & $\mathrm{Z}$ & 6 & 6 & 2 & $\mathrm{Z}$ & 5 & 5 & & & & & 3 & $\mathrm{Z}$ & 5 & 5 & & & & \\
\hline Mersin & 1 & $\mathrm{Z}$ & 6 & 10 & 3 & $\mathrm{Z}$ & 4 & 5 & & & & & 3,4 & $\mathrm{Z}$ & 6 & 10 & 4 & $\mathrm{Z}$ & 3 & 5 \\
\hline M. S.Koçman & 1 & $\mathrm{Z}$ & 6 & 10 & 2 & $\mathrm{Z}$ & 3 & 4 & 2 & $\mathrm{Z}$ & 3 & 4 & 3 & $\mathrm{Z}$ & 6 & 8 & & & & \\
\hline Muş Alparslan & 1 & $\mathrm{Z}$ & 6 & 8 & 3 & $\mathrm{Z}$ & 4 & 5 & & & & & 3 & $\mathrm{Z}$ & 6 & 10 & & & & \\
\hline Nec.Erbakan & 1 & $\mathrm{Z}$ & 6 & 10 & 3 & $\mathrm{Z}$ & 3 & 4 & 4 & $\mathrm{Z}$ & 3 & 5 & 2 & $\mathrm{Z}$ & 3 & 5 & 2 & $\mathrm{~S}$ & 2 & 3 \\
\hline Nişantaş1 & 1 & $\mathrm{Z}$ & 3 & 5 & 2 & $\mathrm{Z}$ & 3 & 5 & & & & & 4 & $\mathrm{~S}$ & 2 & 5 & & & & \\
\hline Ondokuz Mayıs & 1 & $\mathrm{Z}$ & 3 & 6 & 2 & $\mathrm{Z}$ & 4 & 0 & & & & & 3 & $\mathrm{Z}$ & 6 & 0 & & & & \\
\hline S.Bilimleri & 1 & $\mathrm{Z}$ & 6 & 8 & 3 & $\mathrm{Z}$ & 6 & 8 & & & & & 2 & $\mathrm{Z}$ & 6 & 8 & & & & \\
\hline \begin{tabular}{|l|} 
Sakarya \\
\end{tabular} & 1 & $\mathrm{Z}$ & 4 & 5 & 3 & $\mathrm{Z}$ & 3 & 6 & 3 & $\mathbf{S}$ & 2 & 5 & 3 & $\mathrm{Z}$ & 4 & 7 & 4 & $\mathrm{~S}$ & 2 & 5 \\
\hline Selçuk & 1 & $\mathrm{Z}$ & 6 & 12 & 3 & $\mathrm{Z}$ & 3 & 6 & 4 & $\mathrm{Z}$ & 2 & 4 & 3 & $\mathrm{Z}$ & 3 & 5 & 4 & $\mathrm{Z}$ & 3 & 6 \\
\hline S.Cumhuriyet & 1 & $\mathrm{Z}$ & 6 & 9 & 2 & $\mathrm{Z}$ & 3 & 4 & 3,4 & $\mathrm{~S}$ & 2 & 2 & 3 & $\mathrm{Z}$ & 5 & 9 & & & & \\
\hline
\end{tabular}




\begin{tabular}{|l|c|c|c|c|c|c|c|c|c|c|c|c|c|c|c|c|c|c|c|c|}
\hline S.Demirel & 1 & $\mathrm{Z}$ & 6 & 10 & 3 & $\mathrm{Z}$ & 3 & 3 & & & & & 3 & $\mathrm{Z}$ & 6 & 8 & 3 & $\mathrm{~S}$ & 3 & 5 \\
\hline Tokat G.O.P. & 1 & $\mathrm{Z}$ & 6 & 10 & 2 & $\mathrm{Z}$ & 3 & 5 & & & & & 3 & $\mathrm{Z}$ & 3 & 4 & 3 & $\mathrm{~S}$ & 2 & 3 \\
\hline Toros & 2 & $\mathrm{Z}$ & 6 & 8 & 3 & $\mathrm{Z}$ & 3 & 4 & & & & & 3 & $\mathrm{Z}$ & 3 & 4 & & & & \\
\hline Trakya & 1 & $\mathrm{Z}$ & 6 & 8 & 2 & $\mathrm{Z}$ & 3 & 4 & & & & & & & & & & & & \\
\hline Uşak & 1 & $\mathrm{Z}$ & 6 & 10 & 3 & $\mathrm{Z}$ & 4 & 5 & & & & & 3 & $\mathrm{Z}$ & 6 & 10 & & & & \\
\hline Üsküdar & 1 & $\mathrm{Z}$ & 6 & 10 & 3 & $\mathrm{Z}$ & 6 & 8 & & & & & 2 & $\mathrm{Z}$ & 6 & 8 & & & & \\
\hline Doğu Akdeniz & 2 & $\mathrm{Z}$ & 6 & - & 3 & $\mathrm{Z}$ & 3 & - & & & & & 3 & $\mathrm{Z}$ & 6 & - & & & & \\
\hline Girne Amerik. & 1 & $\mathrm{Z}$ & 6 & 10 & 3 & $\mathrm{Z}$ & 3 & 5 & & & & & 2,3 & $\mathrm{Z}$ & 8 & 14 & & & & \\
\hline Ul.Ar.Kıbrıs & 1 & $\mathrm{Z}$ & 3 & - & 3 & $\mathrm{Z}$ & 3 & - & & & & & 2 & $\mathrm{Z}$ & 4 & - & & & & \\
\hline Yakın Doğu & 1 & $\mathrm{Z}$ & 6 & 10 & 3 & $\mathrm{Z}$ & 3 & 5 & & & & & 3 & $\mathrm{Z}$ & 6 & 10 & & & & \\
\hline
\end{tabular}

Kaynak: İlgili yükseköğretim kurumlarının "Kaynakça"da belirtilen resmi web sitelerinden yararlanılarak yazarlar tarafindan oluşturulmuştur.

\subsection{Grup: Muhasebe, Genel Muhasebe ya da Muhasebe İlkeleri Dersleri}

- 67 bölümün; 3’ünde (\%4,48 oranında) bu derslerden herhangi biri ders müfredatında bulunmamaktadır.

- 64 bölümde zorunlu ders statüsünde bulunan derslerin; sınıflara göre dağılımları ve ilgili sinıfta bulunma oranları (\%) olarak şöyledir:

\begin{tabular}{|c|c|c|c|c|c|}
\hline \multicolumn{2}{|c|}{ 1. Sınıf } & \multicolumn{2}{c|}{ 2. Sınıf } & \multicolumn{2}{c|}{ 3. Sınıf } \\
\hline $\begin{array}{c}\text { Bölüm } \\
\text { Sayısı }\end{array}$ & $\begin{array}{c}\text { Oranı } \\
(\boldsymbol{\%})\end{array}$ & $\begin{array}{c}\text { Bölüm } \\
\text { Sayısı }\end{array}$ & $\begin{array}{c}\text { Oranı } \\
(\boldsymbol{\%})\end{array}$ & $\begin{array}{c}\text { Bölüm } \\
\text { Sayısı }\end{array}$ & $\begin{array}{c}\text { Oranı } \\
(\boldsymbol{\%})\end{array}$ \\
\hline 54 & $\% 84,38$ & 8 & $\% 12,5$ & 1 & $\% 1,56$ \\
\hline
\end{tabular}

- 64 bölümdeki toplam 321 ders kredisi üzerinden; derslerin ortalama kredisinin 5,02 olduğu görülmekte ve ders kredilerinin dağılımları ile oranları (\%) aşağıda verilmektedir:

\begin{tabular}{|c|c|c|c|c|c|c|c|}
\hline \multicolumn{2}{|c|}{$\begin{array}{c}2-3 \\
\text { KREDİ }\end{array}$} & \multicolumn{2}{|c|}{$\begin{array}{c}4-5 \\
\text { KREDİ }\end{array}$} & \multicolumn{2}{|c|}{$\begin{array}{c}\text { 6-7 } \\
\text { KREDİ }\end{array}$} & \multicolumn{2}{|c|}{$\begin{array}{c}8-9 \\
\text { KREDİ } \\
\end{array}$} \\
\hline Sayı & $(\%)$ & Sayı & $(\%)$ & Sayı & $(\%)$ & Sayı & $(\%)$ \\
\hline 16 & $\% 25,00$ & 8 & $\% 12,5$ & 39 & $\% 60,94$ & 1 & $\% 1,56$ \\
\hline
\end{tabular}

- AKTS kredisi yerine, ders kredi sistemi uygulanan 2 bölüm dışında kalan, 62 bölümdeki toplam 505 AKTS kredi üzerinden; derslerin ortalama AKTS kredisi 8,15 olarak hesaplanmakta ve AKTS kredi dağılımları ile oranları (\%) aşağıda yer almaktadır.

\begin{tabular}{|c|c|c|c|c|c|c|c|c|c|}
\hline \multicolumn{2}{|c|}{$\begin{array}{c}3-4 \\
\text { AKTS }\end{array}$} & \multicolumn{2}{|c|}{$\begin{array}{c}5-6 \\
\text { AKTS }\end{array}$} & \multicolumn{2}{|c|}{$\begin{array}{c}7-8 \\
\text { AKTS }\end{array}$} & \multicolumn{2}{|c|}{$\begin{array}{c}9-10 \\
\text { AKTS }\end{array}$} & \multicolumn{2}{|c|}{$\begin{array}{r}11-12 \\
\text { AKTS }\end{array}$} \\
\hline Sayı & $(\%)$ & Sayı & $(\%)$ & Sayı & $(\%)$ & Sayı & $(\%)$ & Sayı & $(\%)$ \\
\hline 5 & $\% 8,06$ & 13 & $\% 20,97$ & 13 & $\% 20,97$ & 25 & $\% 40,32$ & 6 & $\% 9,68$ \\
\hline
\end{tabular}

- Derslerin içeriklerine ulaşılan 47 bölüm üzerinde yapılan inceleme sonucunda; derslerde işlenen konu başlıkları ile bu konuların 47 bölümde yer alma oranları (\%) Tablo 4'te verilmektedir. (Örneğin; tablonun 1. satırında yer alan "Alacak-borç işlemleri” konusunun oranı (\%) işlendiği bölüm sayısının (7), ders içeriklerine ulaşılan bölüm sayısına (47) bölünmesiyle elde edilmiştir.) 
Tablo 4. (1. Grup) Muhasebe, Genel Muhasebe ya da Muhasebe İlkeleri Derslerinde İşlenen Konu Başlıklarının Dağılımları

\begin{tabular}{|c|c|c|}
\hline $\begin{array}{c}\text { KONU BAŞLIKLARI } \\
\text { (Alfabetik olarak sıralanmıştır) }\end{array}$ & $\begin{array}{c}\text { Konunun } \\
\text { İşlendiği } \\
\text { Bölüm Sayısı } \\
\text { (47 Bölü̈mde) }\end{array}$ & $\begin{array}{c}\text { Konunun } \\
\text { Yer Alma } \\
\text { Oranı }(\%) \\
(47 \text { Bölümde }) \\
\end{array}$ \\
\hline Alacak- borç işlemleri & 7 & $\% 14,89$ \\
\hline Amortisman & 12 & $\% 25,53$ \\
\hline Ayarlama Kayıtları ve türleri & 1 & $\% 2,13$ \\
\hline Bilanço & 27 & $\% 57,45$ \\
\hline Değerleme Kavramı, ölçüleri & 3 & $\% 6,38$ \\
\hline Dönem başı işlemler & 2 & $\% 4,26$ \\
\hline Dönem içi işlemler & 5 & $\% 10,64$ \\
\hline Dönem Sonu işlemler & 16 & $\% 34,04$ \\
\hline Dönen varlıklar & 30 & $\% 63,83$ \\
\hline Duran varliklar & 33 & $\% 70,21$ \\
\hline Envanter işlemleri & 27 & $\% 57,45$ \\
\hline Faaliyet ve Finansman Gider Hesapları & 2 & $\% 4,26$ \\
\hline Gelir Tablosu & 34 & $\% 72,34$ \\
\hline Gelir-Gider İşlemleri & 28 & $\% 59,57$ \\
\hline Günlük işlemler ve mal alım satım işlemleri & 1 & $\% 2,13$ \\
\hline Hatalı Kayıtların düzeltilmesi & 4 & $\% 8,51$ \\
\hline Hazır değerler & 14 & $\% 29,79$ \\
\hline Hesap kavramı, sınıflandırma, kayıt yöntemleri & 37 & $\% 78,72$ \\
\hline İşlem Sırası & 1 & $\% 2,13$ \\
\hline İşletme varlıkları & 1 & $\% 2,13$ \\
\hline KDV uygulamaları & 12 & $\% 25,53$ \\
\hline Kisa Vadeli Yabanc1 Kaynaklar & 27 & $\% 57,45$ \\
\hline Kullanılması gereken defterler ve kayıt araçları & 29 & $\% 61,70$ \\
\hline Mali (Finansal) Tablolar & 21 & $\% 44,68$ \\
\hline Maliyet Hesapları & 15 & $\% 31,91$ \\
\hline Menkul kıymet işlemleri & 16 & $\% 34,04$ \\
\hline Mizanların düzenlenmesi & 21 & $\% 44,68$ \\
\hline Monografi çalışması & 4 & $\% 8,51$ \\
\hline Muhasebe mesleği & 4 & $\% 8,51$ \\
\hline Muhasebe Standartlar1 & 3 & $\% 6,38$ \\
\hline Muhasebe Uygulamaları & 8 & $\% 17,02$ \\
\hline Muhasebenin tanımı, fonksiyonları, temel kavramları, ilkeleri & 43 & $\% 91,49$ \\
\hline Nakit hareketlerinin muhasebeleştirilmesi & 3 & $\% 6,38$ \\
\hline Ortak Sermaye & 2 & $\% 4,26$ \\
\hline Öz kaynaklar & 31 & $\% 65,96$ \\
\hline Özel Tüketim Vergisi & 1 & $\% 2,13$ \\
\hline Stoklar & 21 & $\% 44,68$ \\
\hline Tek Düzen Hesap Planı & 21 & $\% 44,68$ \\
\hline Ticari Alacaklar ve diğer alacaklar & 18 & $\% 38,30$ \\
\hline Ticari ve diğer borçlar & 8 & $\% 17,02$ \\
\hline Uzun Vadeli Yabancı Kaynaklar & 26 & $\% 55,32$ \\
\hline Ücret Bordrosu ve muhasebeleştirilmesi & 3 & $\% 6,38$ \\
\hline Yönetim raporlamaları & 2 & $\% 4,26$ \\
\hline
\end{tabular}


Kaynak: İlgili yükseköğretim kurumlarının "Kaynakça" da belirtilen resmi web sitelerinden yararlanılarak yazarlar tarafindan oluşturulmuştur.

\subsection{Grup: Maliyet Muhasebesi ile Maliyet Yönetimi Dersleri}

- 67 bölümün 8'inde (\%11.94 oranında) bu derslerden herhangi biri ders müfredatında yer almamaktadır.

- 59 bölümün 57'sinde (\%96,61 oranında) zorunlu ders statüsünde bulunan derslerin, 2 (iki) bölümde (\% 3,39 oranında) seçmeli ders statüsünde verildiği görülmektedir.

- Seçmeli ders statüsünde bulunan 2 (iki) bölümün; 1'inde bu dersler 3. sinıfta verilirken, diğerinde ise 3. ve 4. sınıflarında (6. ve 7. yarıyıllarda) seçmeli ders olarak verilmektedir.

- 57 bölümde zorunlu ders statüsünde bulunan derslerin; sınıflara göre dağılımları ve ilgili sınıfta bulunma oranları, aşağıdaki biçimde karşımıza çıkmaktadır.

\begin{tabular}{|c|c|c|c|c|c|}
\hline \multicolumn{2}{|c|}{ 2. Sınıf } & \multicolumn{2}{c|}{ 3. Sınıf } & \multicolumn{2}{c|}{ 4. Sınıf } \\
\hline $\begin{array}{c}\text { Bölüm } \\
\text { Sayısı }\end{array}$ & $\begin{array}{c}\text { Oranı } \\
(\boldsymbol{\%})\end{array}$ & $\begin{array}{c}\text { Bölüm } \\
\text { Sayısı }\end{array}$ & $\begin{array}{c}\text { Oranı } \\
(\boldsymbol{\%})\end{array}$ & $\begin{array}{c}\text { Bölüm } \\
\text { Sayısı }\end{array}$ & $\begin{array}{c}\text { Oranı } \\
(\boldsymbol{\%})\end{array}$ \\
\hline 29 & $\% 50,88$ & 27 & $\% 47,37$ & 1 & $\% 1,75$ \\
\hline
\end{tabular}

- 59 bölümde bulunan derslerin, toplam 198 ders kredisi üzerinden; ortalama kredisinin 3,36 olduğu görülmekte ve ders kredilerinin dağılımları ile oranları (\%) aşağıda verilmektedir.

\begin{tabular}{|c|c|c|c|c|c|c|c|}
\hline \multicolumn{2}{|c|}{$\begin{array}{c}2-3 \\
\text { KREDİ }\end{array}$} & \multicolumn{2}{|c|}{$\begin{array}{c}4-5 \\
\text { KREDİ }\end{array}$} & \multicolumn{2}{|c|}{$\begin{array}{c}\text { 6-7 } \\
\text { KREDİ }\end{array}$} & \multicolumn{2}{|c|}{$\begin{array}{c}8-9 \\
\text { KREDİ }\end{array}$} \\
\hline Sayı & $(\%)$ & Sayı & $(\%)$ & Sayı & $(\%)$ & Sayı & $(\%)$ \\
\hline 47 & $\% 79,66$ & 6 & $\% 10,17$ & 6 & $\% 10,17$ & 0 & $\% 0,00$ \\
\hline
\end{tabular}

- AKTS kredisi yerine ders kredi sistemi uygulanan 2 bölüm dışında kalan, 57 bölümdeki toplam 291 AKTS kredi üzerinden; derslerin ortalama AKTS kredisi 5,11 olarak hesaplanmakta ve AKTS kredi dağılımları ile oranları (\%) aşağıda yer almaktadır.

\begin{tabular}{|c|c|c|c|c|c|c|c|c|c|c|c|c|c|}
\hline \multicolumn{2}{|c|}{$\begin{array}{c}0 \\
\text { AKTS }\end{array}$} & \multicolumn{2}{|c|}{$\begin{array}{c}3-4 \\
\text { AKTS }\end{array}$} & \multicolumn{2}{|c|}{$\begin{array}{c}5-6 \\
\text { AKTS }\end{array}$} & \multicolumn{2}{|c|}{$\begin{array}{r}7-8 \\
\text { AKTS }\end{array}$} & \multicolumn{2}{|c|}{$\begin{array}{c}9-10 \\
\text { AKTS }\end{array}$} & \multicolumn{2}{|c|}{$\begin{array}{c}\text { 11-12 } \\
\text { AKTS }\end{array}$} & \multicolumn{2}{|c|}{$\begin{array}{c}13 \\
\text { AKTS }\end{array}$} \\
\hline Sayı & $(\%)$ & Sayı & $(\%)$ & Sayı & $(\%)$ & Sayı & $(\%)$ & Sayı & $(\%)$ & Sayı & $(\%)$ & Sayı & $(\%)$ \\
\hline 2 & $\% 3,51$ & 17 & $\% 29,82$ & 32 & $\% 56,14$ & 3 & $\% 5,26$ & 2 & $\% 3,51$ & 0 & $\% 0,00$ & 1 & $\% 1,7$ \\
\hline
\end{tabular}

- Derslerin içeriklerine ulaşılan 39 bölümde; derslerde işlenen konu başlıkları ile bu konuların 39 bölümde yer alma oranları (\%) Tablo 5 'te verilmektedir. 
Tablo 5. (2. Grup) Maliyet Muhasebesi ile Maliyet Yönetimi Derslerinde İşı̇enen Konu Başlıklarının Dağılımları

\begin{tabular}{|c|c|c|}
\hline $\begin{array}{c}\text { KONU BAŞLIKLARI } \\
\text { (Alfabetik olarak stralanmıştır) }\end{array}$ & $\begin{array}{c}\text { Konunun } \\
\text { İşlendiği } \\
\text { Bölüm Sayısı } \\
\text { (39 Bölümde) }\end{array}$ & $\begin{array}{c}\text { Konunun Yer } \\
\text { Alma } \\
\text { Oranı }(\%) \\
(39 \text { Bölümde })\end{array}$ \\
\hline 7/A Seçeneği & 11 & $\% 28,21$ \\
\hline 7/B Seceneăi & 7 & $\% 17,95$ \\
\hline Başabaş noktası & 5 & $\% 12,82$ \\
\hline Birim Maliyetlerinin hesaplanmas1 & 9 & $\% 23,08$ \\
\hline Bütçe yaklaşımları & 5 & $\% 12,82$ \\
\hline Doğrudan-dolaylı Maliyetler & 1 & $\% 2,56$ \\
\hline Dönem içi işlemleri & 3 & $\% 7,69$ \\
\hline Dönem Sonu İşlemleri & 5 & $\% 12,82$ \\
\hline Esas ve yardımc1 giderler & 1 & $\% 2,56$ \\
\hline Eşdeğer ürün & 1 & $\% 2,56$ \\
\hline Faaliyet tabanlı-esaslı maliyetleme & 3 & $\% 7,69$ \\
\hline Fire ve bozuk mamuller & 4 & $\% 10,26$ \\
\hline Gelir Tablosu & 3 & $\% 7,69$ \\
\hline Genel Üretim Giderleri-maliyetleri & 19 & $\% 48,72$ \\
\hline Gider Dağıtımı-sınıflandırması ve Muhasebeleştirilmesi & 24 & $\% 61,54$ \\
\hline Giderlerin 1. Dağıtımı & 12 & $\% 30,77$ \\
\hline Giderlerin 2. Dağıtımı & 12 & $\% 30,77$ \\
\hline Giderlerin 3. Dağıtımı & 8 & $\% 20,51$ \\
\hline Güvenlik payı ve oranı & 1 & $\% 2,56$ \\
\hline Hammadde - malzeme & 2 & $\% 5,13$ \\
\hline Hesapların işleyişi & 7 & $\% 17,95$ \\
\hline Hizmet maliyet sistemleri & 6 & $\% 15,38$ \\
\hline Hizmet merkezleri ve dağıtım anahtarları & 3 & $\% 7,69$ \\
\hline İlk Madde ve malzeme & 24 & $\% 61,54$ \\
\hline İşçilik maliyetleri-giderleri & 26 & $\% 66,67$ \\
\hline JIT ve kalite maliyetleri & 1 & $\% 2,56$ \\
\hline Kapsamına göre Maliyet Yöntemleri & 1 & $\% 2,56$ \\
\hline Karar almada bilgilerin kullanılması & 6 & $\% 15,38$ \\
\hline Katk1 pay1 ve oranı & 1 & $\% 2,56$ \\
\hline Maliyet Analizleri (Maliyet-Hacim-Kâr vb.) & 18 & $\% 46,15$ \\
\hline Maliyet (Maliyet Muhasebesi) Kavramı, tanımı, önemi & 36 & $\% 92,31$ \\
\hline Maliyet Sınıflandırmaları, unsurları & 20 & $\% 51,28$ \\
\hline Maliyet yöntemleri-sistemleri & 26 & $\% 66,67$ \\
\hline Mamul-Yarı mamul hesaplar & 2 & $\% 5,13$ \\
\hline Mamul Yaşam Seyri & 1 & $\% 2,56$ \\
\hline Raporlama & 7 & $\% 17,95$ \\
\hline Satılan Malların-satışların maliyeti & 6 & $\% 15,38$ \\
\hline Servis maliyeti & 1 & $\% 2,56$ \\
\hline Sipariş-safha-karma maliyet & 11 & $\% 28,21$ \\
\hline Stoklar & 9 & $\% 23,08$ \\
\hline Stratejik Maliyet Yönetimi & 1 & $\% 2,56$ \\
\hline Talep tahmin yöntemleri & 1 & $\% 2,56$ \\
\hline Tekdüzen Hesap Planında Maliyet hesapları & 9 & $\% 23,08$ \\
\hline Tüketici tahsisleri & 1 & $\% 2,56$ \\
\hline Uygulama örnekleri, problem çözme & 13 & $\% 33,33$ \\
\hline
\end{tabular}


Kaynak: İlgili yükseköğretim kurumlarının "Kaynakça" da belirtilen resmi web sitelerinden yararlanılarak yazarlar tarafindan oluşturulmuştur.

\subsection{Grup: Yönetim Muhasebesi Dersi}

- 64 bölümün 16'sında (\%25,00 oranında) bu ders, ders müfredatında yer almaktadır.

- Yönetim Muhasebesi dersi, 1. Grup dersler (Muhasebe/Genel Muhasebe/Muhasebe İlkeleri) içerisinde sınıflandırılabilir. Ancak Fakülte müfredatlarında, hem 1. Grup derslerinin hem de "Yönetim Muhasebesi" dersinin yer alması nedeniyle, bu ders ayrı olarak 3. Grup'ta değerlendirilmiştir.

- 16 bölümün 6'sında (\%37,5 oranında) zorunlu ders statüsünde bulunan dersin, diğer 10 bölümde (\%62,5 oranında) seçmeli ders statüsünde verildiği görülmektedir.

- 6 bölümde zorunlu, 10 bölümde seçmeli ders statüsünde bulunan dersin sinıflara göre dağılımları ve ilgili sınıfta bulunma oranları şöyledir:

\begin{tabular}{|c|c|c|c|c|c|c|}
\hline \multirow{2}{*}{$\begin{array}{c}\text { Ders Statüsü } \\
\text { (Zorunlu/Seçmeli) }\end{array}$} & $\begin{array}{c}\text { 2. Sı̈ıf } \\
\text { Sayı̈ım }\end{array}$ & $\begin{array}{c}\text { Oranı } \\
(\boldsymbol{\%})\end{array}$ & $\begin{array}{c}\text { Bölüm } \\
\text { Sayısı }\end{array}$ & $\begin{array}{c}\text { Oranı } \\
(\boldsymbol{\%})\end{array}$ & $\begin{array}{c}\text { Bölüm } \\
\text { Sayısı }\end{array}$ & $\begin{array}{c}\text { Oranı } \\
(\boldsymbol{\%})\end{array}$ \\
\hline Zorunlu (6 Bölüm) & 3 & $\% 50$ & 1 & $\% 16,67$ & 2 & $\% 33,33$ \\
\hline Seçmeli (8 Bölüm) (*) & 0 & $\% 0,00$ & 4 & $\% 50$ & 4 & $\% 50$ \\
\hline
\end{tabular}

(*) Seçmeli ders statüsünde bulunan diğer 2 ders 6. ve 7. Yarıyıllarda (3. ve 4. sınıf) verilmektedir.

- 16 bölümde bulunan dersin, toplam 42 ders kredisi üzerinden; ortalama kredisinin 3,38 olduğu görülmekte ve ders kredilerinin dağılımları ile oranları (\%) aşağıda verilmektedir.

\begin{tabular}{|c|c|c|c|c|c|}
\hline \multicolumn{2}{|c|}{$\begin{array}{c}\text { 2 } \\
\text { KREDI }\end{array}$} & \multicolumn{2}{c|}{$\begin{array}{c}c \mid \\
\text { KREDI }\end{array}$} & \multicolumn{2}{c|}{ KREDI் } \\
\hline Sayı & $(\%)$ & Sayı & $(\%)$ & Sayı & $(\%)$ \\
\hline 6 & $\% 37,5$ & 10 & $\% 62,5$ & 0 & $\% 0,00$ \\
\hline
\end{tabular}

- 16 bölümdeki toplam 64 AKTS kredi üzerinden; dersin ortalama AKTS kredisi 4 olarak hesaplanmakta ve AKTS kredi dağılımları ile oranları (\%) aşağıda yer almaktadır.

\begin{tabular}{|c|c|c|c|c|c|c|c|}
\hline \multicolumn{2}{|c|}{ 1-2 AKTS } & \multicolumn{2}{c|}{ 3-4 AKTS } & \multicolumn{2}{c|}{ 5-6 AKTS } & \multicolumn{2}{c|}{ 7-8 AKTS } \\
\hline Sayı & $(\%)$ & Sayı & $(\%)$ & Sayı & $(\%)$ & Sayı & $(\%)$ \\
\hline 1 & $\% 6,25$ & 10 & $\% 62,5$ & 5 & $\% 31,25$ & 0 & $\% 0,00$ \\
\hline
\end{tabular}

- Ders içeriklerine ulaşılan 11 bölüm üzerinde yapılan inceleme sonucunda; derslerde işlenen konu başlıkları ile bu konuların 11 bölümde yer alma oranları (\%) Tablo 6'da verilmektedir. 
Tablo 6. (3. Grup) Yönetim Muhasebesi Dersinde İşlenen Konu Başlıklarının Dağılımları

\begin{tabular}{|c|c|c|}
\hline $\begin{array}{c}\text { KONU BAŞLIKLARI } \\
\text { (Alfabetik olarak sıralanmıştır) }\end{array}$ & $\begin{array}{c}\text { Konunun } \\
\text { İşlendiği } \\
\text { Bölüm Sayısı } \\
\text { (11 Bölü̈mde) }\end{array}$ & $\begin{array}{c}\text { Konunun } \\
\text { Yer Alma } \\
\text { Oranı (\%) } \\
\text { (11 Bölümde) }\end{array}$ \\
\hline Barkod uygulamas1 & 1 & $\% 9,09$ \\
\hline Başabaş noktas1 & 2 & $\% 18,18$ \\
\hline Bütçe işlemleri & 7 & $\% 63,64$ \\
\hline Değer zinciri & 1 & $\% 9,09$ \\
\hline Depolama & 1 & $\% 9,09$ \\
\hline Etik & 1 & $\% 9,09$ \\
\hline Faaliyet kaldıracı & 2 & $\% 18,18$ \\
\hline Faaliyet kontrolü ve planlamas1 & 1 & $\% 9,09$ \\
\hline Finansal tablolara geçiş & 2 & $\% 18,18$ \\
\hline Fiyatlama, hedef maliyetleme & 2 & $\% 18,18$ \\
\hline Gider yerlerinin saptanmas1 & 1 & $\% 9,09$ \\
\hline Girdi-çıktı kavramı & 1 & $\% 9,09$ \\
\hline Güven pay1 & 2 & $\% 18,18$ \\
\hline İhtiyaç tespiti & 1 & $\% 9,09$ \\
\hline İlk madde ve malzeme & 1 & $\% 9,09$ \\
\hline İşçilik giderleri & 1 & $\% 9,09$ \\
\hline Kar amaçlı kuruluş ile kar amacı gütmeyen kuruluş fark1 & 1 & $\% 9,09$ \\
\hline Kısa vadeli karar verme, hızlı karar alma & 2 & $\% 18,18$ \\
\hline Lojistik yönetimi & 2 & $\% 18,18$ \\
\hline Mal teslimi, satın alma denetimi, mal giriş-çıkışı & 2 & $\% 18,18$ \\
\hline Maliyet analizi uygulamaları (maliyet-hacim-kâr) & 9 & $\% 81,82$ \\
\hline Maliyet yöntemleri, sınıflandırma, unsurları & 8 & $\% 72,73$ \\
\hline Malzeme döngüsü unsurları & 1 & $\% 9,09$ \\
\hline Malzemelerin kullanıma hazırlanılması ve steril süreçler & 1 & $\% 9,09$ \\
\hline Muhasebe verilerinin yönetimde kullanılması & 5 & $\% 45,45$ \\
\hline Paydaşlar ve tedarikçiler & 1 & $\% 9,09$ \\
\hline Rekabet & 1 & $\% 9,09$ \\
\hline Satın alma ahlak ilkeleri & 1 & $\% 9,09$ \\
\hline Sorumluluk muhasebesi & 2 & $\% 18,18$ \\
\hline Stok plânlaması, yönetimi, kontrolü & 6 & $\% 54,55$ \\
\hline Uygulama & 4 & $\% 36,36$ \\
\hline Verimlilik ve etkililik & 1 & $\% 9,09$ \\
\hline Yabancı kaynakların yönetimi & 2 & $\% 18,18$ \\
\hline Yöneticilerin etkinliğini ölçümleme & 1 & $\% 9,09$ \\
\hline Yönetim kontrolü & 1 & $\% 9,09$ \\
\hline Yönetim, Yönetim Muhasebesi kavramı, tanımı, önemi & 10 & $\% 90,91$ \\
\hline
\end{tabular}

Kaynak: İlgili yükseköğretim kurumlarının "Kaynakça" da belirtilen resmi web sitelerinden yararlanılarak yazarlar tarafindan oluş̧urulmuştur.

\subsection{Grup: Finans Yönetimi ile Finansal Yönetim Dersleri}

- 67 bölümün 3'ünde (\%4,48 oranında) bu derslerden herhangi biri, ders müfredatında yer almamaktadır. 
- 64 bölümün 63'ünde (\%98,44 oranında) zorunlu ders statüsünde bulunan derslerin, sınıflara göre dağılımları ve ilgili sınıfta bulunma oranları aşağıdaki biçimde hesaplanmaktadır:

\begin{tabular}{|c|c|c|c|c|c|c|c|}
\hline \multicolumn{2}{|c|}{ 1. Sınıf (*) } & \multicolumn{2}{c|}{ 2. Sınıf (*) } & \multicolumn{2}{c|}{ 3. Sınıf (*) } & \multicolumn{2}{c|}{ 4. Sınıf (*) } \\
\hline $\begin{array}{c}\text { Bölüm } \\
\text { Sayısı }\end{array}$ & $\begin{array}{c}\text { Oranı } \\
(\boldsymbol{\%})\end{array}$ & $\begin{array}{c}\text { Bölüm } \\
\text { Sayısı }\end{array}$ & $\begin{array}{c}\text { Oranı } \\
(\boldsymbol{\%})\end{array}$ & $\begin{array}{c}\text { Bölüm } \\
\text { Sayısı }\end{array}$ & $\begin{array}{c}\text { Oranı } \\
(\boldsymbol{\%})\end{array}$ & $\begin{array}{c}\text { Bölüm } \\
\text { Sayısı }\end{array}$ & $\begin{array}{c}\text { Oranı } \\
(\boldsymbol{\%})\end{array}$ \\
\hline 1 & $\% 1,64$ & 14 & $\% 22,95$ & 43 & $\% 70,49$ & 3 & $\% 4,92$ \\
\hline
\end{tabular}

(*) Sayı ve oranlar 61 bölüm üzerinden hesaplanmıştır.

Dağılımdaki toplam 61 bölüm dışında kalan diğer 2 bölümden 1'inde bu dersler 2 ve 3. sınıflarda (4. ve 5. yarıyıllarda), diğerinde ise 3. ve 4. sinıflarda (6. ve 7. yarıyıllarda) yer almaktadır.

- Seçmeli ders statüsünde bulunan 1 bölümde (\%1,56 oranında) 4. sınıfta yer aldığ görülmektedir.

- 64 bölümde bulunan derslerin, toplam 298 ders kredisi üzerinden; ortalama kredisinin 4,66 olduğu görülmekte ve dağılım ile oranları (\%) aşağıda verilmektedir.

\begin{tabular}{|c|c|c|c|c|c|c|c|}
\hline \multicolumn{2}{|c|}{ 2-3 KREDI் } & \multicolumn{2}{c|}{ 4-5 KREDI் } & \multicolumn{2}{c|}{ 6-7 KREDI் } & \multicolumn{2}{c|}{ 8-9 KREDI் } \\
\hline Sayı & $(\boldsymbol{\%})$ & Sayı & $(\boldsymbol{\%})$ & Sayı & $(\%)$ & Sayı & $(\boldsymbol{\%})$ \\
\hline 24 & $\% 37,5$ & 9 & $\% 14,06$ & 29 & $\% 45,31$ & 2 & $\% 3,13$ \\
\hline
\end{tabular}

- AKTS kredisi yerine ders kredi sistemi uygulanan 2 bölüm dışında kalan, 62 bölümdeki toplam 453 AKTS kredi üzerinden; derslerin ortalama AKTS kredisi 7,31 olarak hesaplanmakta ve AKTS kredi dağılımları ile oranları (\%) aşağıda yer almaktadır.

\begin{tabular}{|c|c|c|c|c|c|c|c|c|c|c|c|c|c|}
\hline \multicolumn{2}{|c|}{0 AKTS } & \multicolumn{2}{|c|}{ 3-4 AKTS } & \multicolumn{2}{|c|}{ 5-6 AKTS } & \multicolumn{2}{|c|}{ 7-8 AKTS } & \multicolumn{2}{|c|}{ 9-10 AKTS } & \multicolumn{2}{|c|}{ 11-12 AKTS } & \multicolumn{2}{|c|}{ 13-14 AKTS } \\
\hline Sayı & $(\%)$ & Sayı & $(\%)$ & Sayı & $(\%)$ & Sayı & $(\%)$ & Sayı & $(\%)$ & Sayı & $(\%)$ & Sayı & $(\%)$ \\
\hline 1 & $\% 1,61$ & 6 & $\% 9,68$ & 19 & $\% 30,65$ & 14 & $\% 22,58$ & 20 & $\% 32,26$ & 1 & $\% 1,61$ & 1 & $\% 1,61$ \\
\hline
\end{tabular}

- Derslerin içeriklerine ulaşılan 44 bölüm üzerinde yapılan inceleme sonucunda; derslerde işlenen konu başlıkları ile bu konuların 44 bölümde yer alma oranları (\%) Tablo 7'de verilmektedir.

Tablo 7. (4. Grup) Finans Yönetimi ile Finansal Yönetim Derslerinde İşlenen Konu Başlıklarının Dağılımları

\begin{tabular}{|l|c|c|}
\hline \multicolumn{1}{|c|}{$\begin{array}{c}\text { KONU BAŞLIKLARI } \\
\text { (Alfabetik olarak siralanmıştır) }\end{array}$} & $\begin{array}{c}\text { Konunun } \\
\text { İşlendiği } \\
\text { Bölüm Sayısı } \\
\text { (44 Bölümde) }\end{array}$ & $\begin{array}{c}\text { Konunun } \\
\text { Yer Alma } \\
\text { Oranı (\%) } \\
\text { (44 Bölümde) }\end{array}$ \\
\hline Alacak yönetimi & 21 & $\% 47,73$ \\
\hline Başabaş noktas1 & 11 & $\% 25,00$ \\
\hline Bütçeleme & 31 & $\% 70,45$ \\
\hline Denetim & 11 & $\% 25,00$ \\
\hline Döner sermaye uygulamaları, bütçesi & 5 & $\% 11,36$ \\
\hline Döviz kurları & 1 & $\% 2,27$ \\
\hline Enflasyon ve faiz oranları, faiz hesaplamaları & 13 & $\% 29,55$ \\
\hline Finans matematiği & 3 & $\% 6,82$ \\
\hline Finans, Finansal Yönetim, kavram1, tanım1, önemi vb. & 37 & $\% 84,09$ \\
\hline
\end{tabular}




\begin{tabular}{|c|c|c|}
\hline Finansal örgütlenme, organizasyon & 12 & $\% 27,27$ \\
\hline Finansal pazarlama & 1 & $\% 2,27$ \\
\hline Finansal piyasalar ve araçlar & 8 & $\% 18,18$ \\
\hline Finansal planlama yöntemleri & 28 & $\% 63,64$ \\
\hline Finansal raporlama & 7 & $\% 15,91$ \\
\hline Finansal sorunlar & 2 & $\% 4,55$ \\
\hline Finansal (mali) Tablolar, analiz teknikleri & 33 & $\% 75,00$ \\
\hline Finansman kaynakları & 13 & $\% 29,55$ \\
\hline Firma değeri & 9 & $\% 20,45$ \\
\hline Fiyatlama, fiyatlandirma & 7 & $\% 15,91$ \\
\hline Fon ak1m tablosu & 1 & $\% 2,27$ \\
\hline Gelecek trendleri, yeni finansman teknikleri & 4 & $\% 9,09$ \\
\hline Geri ödeme süresi & 3 & $\% 6,82$ \\
\hline Hisse senedi & 9 & $\% 20,45$ \\
\hline İç getiri oranı ve karlılık endeksi & 1 & $\% 2,27$ \\
\hline Kaldıraç analizleri, dereceleri & 5 & $\% 11,36$ \\
\hline Kâr Planlaması / Kâr payı dağıtımı & 13 & $\% 29,55$ \\
\hline Kredilendirme süreci & 2 & $\% 4,55$ \\
\hline Likidite & 1 & $\% 2,27$ \\
\hline Menkul kiymetler & 3 & $\% 6,82$ \\
\hline Mevduat hesaplarının getirileri & 1 & $\% 2,27$ \\
\hline Nakit yönetimi, nakit akımı & 28 & $\% 63,64$ \\
\hline Net bugünkü (şimdiki) değer, anüite hesaplamaları & 13 & $\% 29,55$ \\
\hline Ödeme yöntemleri & 1 & $\% 2,27$ \\
\hline Özellikli durumlar (başarısızlık, kriz vb.), katostrofik harcamalar & 5 & $\% 11,36$ \\
\hline Özkaynak yönetimi & 13 & $\% 29,55$ \\
\hline Paranın zaman değeri & 19 & $\% 43,18$ \\
\hline Proje değerleme yöntemleri & 8 & $\% 18,18$ \\
\hline Risk, getiri & 14 & $\% 31,82$ \\
\hline Sermaye yönetimi, sermaye yapıs1 & 36 & $\% 81,82$ \\
\hline Stok yönetimi & 24 & $\% 54,55$ \\
\hline Sürdürülebilir büyüme, iç verim & 5 & $\% 11,36$ \\
\hline Tahvil, kavramı-değerlemesi & 9 & $\% 20,45$ \\
\hline Taşınır kayıt ve kontrolü, muhasebesi & 2 & $\% 4,55$ \\
\hline Türev ürünler & 2 & $\% 4,55$ \\
\hline Uygulama, örnek soru çözümü & 8 & $\% 18,18$ \\
\hline Varlıkların yönetimi & 11 & $\% 25,00$ \\
\hline Yabancı kaynak yönetimi & 12 & $\% 27,27$ \\
\hline Yatırım kararları, karar verme teknikleri & 19 & $\% 43,18$ \\
\hline
\end{tabular}

Kaynak: İlgili yükseköğretim kurumlarının "Kaynakça" da belirtilen resmî web sitelerinden yararlanılarak yazarlar tarafindan oluşturulmuştur.

\section{5. 5. Grup: Mali Tablolar Analizi, Finansal Tablolar Analizi ya da Mali Analiz Yönetimi Dersleri}

- 64 bölümün 22'sinde (\%34,38 oranında) bu derslerden herhangi biri, ders müfredatında yer almaktadır.

- 22 bölümün 7'sinde (\%31,82 oranında) zorunlu ders statüsünde bulunan dersler, diğer 15 bölümde (\%68,18 oranında) seçmeli ders statüsünde bulunmakta, derslerin sınıflara göre dağılımları ve ilgili sınıfta bulunma oranları aşağıda verilmektedir. 


\begin{tabular}{|c|l|c|c|c|c|c|}
\hline \multirow{2}{*}{$\begin{array}{c}\text { Ders Statüsü } \\
\text { (Zorunlu/Seçmeli) }\end{array}$} & $\begin{array}{c}\text { 2. Sölüm } \\
\text { Sayısı }\end{array}$ & $\begin{array}{c}\text { Oranı } \\
(\%)\end{array}$ & $\begin{array}{c}\text { Bölüm } \\
\text { Sayısı }\end{array}$ & $\begin{array}{c}\text { Oranı } \\
(\%)\end{array}$ & $\begin{array}{c}\text { Bölüm } \\
\text { Sayısı }\end{array}$ & $\begin{array}{c}\text { Oranı } \\
(\%)\end{array}$ \\
\hline Zorunlu (7 Bölüm) & 2 & $\% 28,57$ & 3 & $\% 42,86$ & 2 & $\% 28,57$ \\
\hline Seçmeli (15 Bölüm) & 3 & $\% 20$ & 5 & $\% 33,33$ & 7 & $\% 26,67$ \\
\hline
\end{tabular}

- 22 bölümde bulunan derslerin, toplam 57 ders kredisi üzerinden; ortalama kredisinin 2,59 olduğu görülmekte ve ders kredilerinin dağılımları ile oranları (\%) aşağıda verilmektedir.

\begin{tabular}{|c|c|c|c|c|c|c|c|}
\hline \multicolumn{2}{|c|}{ 0 KREDI } & \multicolumn{2}{c|}{ 2 KREDI } & \multicolumn{2}{c|}{ 3 KREDİ } & \multicolumn{2}{c|}{ 4 KREDI் } \\
\hline Sayı & $(\boldsymbol{\%})$ & Sayı & $(\boldsymbol{\%})$ & Sayı & $(\boldsymbol{\%})$ & Sayı & $(\boldsymbol{\%})$ \\
\hline 1 & $\% 4,55$ & 6 & $\% 27,27$ & 15 & $\% 68,18$ & 0 & $\% 0,00$ \\
\hline
\end{tabular}

- 22 bölümdeki toplam 93 AKTS kredi üzerinden; derslerin ortalama AKTS kredisi 4,23 olarak hesaplanmakta ve AKTS kredi dağılımları ile oranları (\%) aşağıda yer almaktadır.

\begin{tabular}{|c|c|c|c|c|c|c|c|}
\hline \multicolumn{2}{|c|}{ 0-2 AKTS } & \multicolumn{2}{c|}{ 3-4 AKTS } & \multicolumn{2}{c|}{ 5-6 AKTS } & \multicolumn{2}{c|}{ 7-8 AKTS } \\
\hline Sayı & $(\boldsymbol{\%})$ & Sayı & $(\boldsymbol{\%})$ & Sayı & $(\boldsymbol{\%})$ & Sayı & $(\boldsymbol{\%})$ \\
\hline 0 & $\% 0,00$ & 13 & $\% 59,09$ & 9 & $\% 40,91$ & 0 & $\% 0,00$ \\
\hline
\end{tabular}

- Derslerin içeriklerine ulaşılan 15 bölüm üzerinde yapılan inceleme sonucunda; derslerde işlenen konu dağılımları ile konuların 15 bölümde yer alma oranları (\%) Tablo 8'de verilmektedir.

Tablo 8. (5.Grup) Mali Tablolar Analizi, Finansal Tablolar Analizi ya da Mali Analiz Yönetimi Derslerinde İşlenen Konu Başlıklarının Dağılımları

\begin{tabular}{|l|c|c|}
\hline \multicolumn{1}{|c|}{$\begin{array}{c}\text { KONU BAŞLIKLARI } \\
\text { (Alfabetik olarak sıralanmıştır) }\end{array}$} & $\begin{array}{c}\text { Konunun } \\
\text { İslendiği } \\
\text { Bölüm Sayısı } \\
(\mathbf{1 5} \text { Böliümde) }\end{array}$ & $\begin{array}{c}\text { Konunun } \\
\text { Yer Alma } \\
\text { Oranı (\%) } \\
\text { (15 Bölümde) }\end{array}$ \\
\hline Analiz raporu & 6 & $\% 40,00$ \\
\hline Bilanço & 8 & $\% 53,33$ \\
\hline Değerleme işlemleri (hisse senedi tahvil) & 2 & $\% 13,33$ \\
\hline Enflasyon muhasebesi & 1 & $\% 6,67$ \\
\hline Enflasyonun tablolar üzerine etkisi & 1 & $\% 6,67$ \\
\hline Finansal (mali) tablolar, analiz teknikleri-yöntemleri & 11 & $\% 73,33$ \\
\hline Gelir tablosunun önemi & 8 & $\% 53,33$ \\
\hline Karş1laştırma & 5 & $\% 33,33$ \\
\hline Kavramı, tanımı, önemi, amacı & 10 & $\% 66,67$ \\
\hline Muhasebe süreci, sistemleri & 2 & $\% 13,33$ \\
\hline Nakit Akımı & 3 & $\% 20,00$ \\
\hline Uygulama & 5 & $\% 33,33$ \\
\hline Yorumlama, değerlendirme & 6 & $\% 40,00$ \\
\hline
\end{tabular}

Kaynak: İlgili yükseköğretim kurumlarının "Kaynakça" da belirtilen resmî web sitelerinden yararlanılarak yazarlar tarafindan oluşturulmuştur. 


\subsection{Muhasebe ve Finans Disiplinleri İçerisinde Yer Alan Diğer Dersler}

Sağlık Yönetimi alanında, lisans düzeyinde eğitim verilen 76 bölümden, müfredatlarına erişilebilen 67 bölümün dersleri incelendiğinde; Tablo 3'te yer alan derslerin yanı sıra az sayıda da olsa, muhasebe ve finans disiplinine uyan farklı derslerin de yer aldığ 1 görülmektedir.

Az sayıda bulunan bu derslere Tablo 3'te yer verilememiş olup aşağıdaki başlıklar altında ele alınmıştır.

\subsubsection{Muhasebe disiplini içerisinde yer alan diğer dersler}

Muhasebe disiplini içerisinde yer alan az sayıdaki diğer derslere ilişkin dağılımlar Tablo 9'da yer almaktadir.

Tablo 9. Muhasebe Disiplini İçerisinde Yer Alan Diğer Derslerin Dağılımları

\begin{tabular}{|c|c|c|c|c|c|c|c|c|}
\hline Üniversite & Dersin Adı & $\begin{array}{c}\text { Ders } \\
\text { Statï } \\
\text { Z/S }\end{array}$ & $\begin{array}{l}\text { Dersin } \\
\text { Kredisi }\end{array}$ & $\begin{array}{c}\text { Bölüm } \\
\text { Kredi } \\
\text { Toplamı }\end{array}$ & $\begin{array}{c}\text { Dersin } \\
\text { Bölüm } \\
\text { Kredi } \\
\text { Toplamına } \\
\text { Oranı (\%) }\end{array}$ & $\begin{array}{l}\text { Dersin } \\
\text { AKTS } \\
\text { Kredisi }\end{array}$ & $\begin{array}{c}\text { Bölüm } \\
\text { AKTS } \\
\text { Toplamı }\end{array}$ & $\begin{array}{c}\text { Dersin } \\
\text { Bölüm } \\
\text { AKTS } \\
\text { Toplamına } \\
\text { Oranı (\%) }\end{array}$ \\
\hline Bayburt & Şirketler Muh. & $\mathrm{Z}$ & 3 & 190 & $\% 1,58$ & 4 & 240 & $\% 1,67$ \\
\hline Bayburt & Vergi Muh. & $\mathrm{S}$ & 3 & 190 & $\% 1,58$ & 3 & 240 & $\% 1,25$ \\
\hline Bezm-i Al & Ön Muhasebe & $\mathrm{Z}$ & 2 & 170 & $\% 1,18$ & 2 & 240 & $\% 0,83$ \\
\hline E. B. Yild. & S̆g.İşl. Şirk.M & $\mathrm{S}$ & 0 & 65 & $\% 0,00$ & 4 & 240 & $\% 1,67$ \\
\hline E. B. Y1ld & Sağ.İşı. Muh. D & $\mathrm{Z}$ & 0 & 65 & $\% 0,00$ & 4 & 240 & $\% 1,67$ \\
\hline İst. Arel & Muh. Giriş & $\mathrm{Z}$ & 3 & 155 & $\% 1,94$ & 5 & 240 & $\% 2,08$ \\
\hline İst. Aydın & Muh. Giriş & $\mathrm{Z}$ & 3 & 173 & $\% 1,73$ & 5 & 240 & $\% 2,08$ \\
\hline İst. Bilgi & S̆g. Kur. Muh. & $\mathrm{Z}$ & 3 & 182 & $\% 1,65$ & 5 & 240 & $\% 2,08$ \\
\hline İst. Bilgi & Ul.Ar.Fin.Muh & $\mathrm{S}$ & 3 & 182 & $\% 1,65$ & 6 & 240 & $\% 2,50$ \\
\hline İst. Gelişim & Sigorta Muh. & $\mathrm{Z}$ & 3 & 165 & $\% 1,82$ & 6 & 240 & $\% 2,50$ \\
\hline İst. Gelişim & Medikal Muh. & $\mathrm{S}$ & 3 & 165 & $\% 1,82$ & 6 & 240 & $\% 2,50$ \\
\hline İst. S. Zaim & Fin. Muh.Giriş & $\mathrm{S}$ & 3 & 155,5 & $\% 1,93$ & 5 & 240 & $\% 2,08$ \\
\hline S. Demirel & Muh. Paket Pr & $\mathrm{S}$ & 3 & 158,5 & $\% 1,89$ & 5 & 235 & $\% 2,13$ \\
\hline S. Demirel & S̆g Kur.Ma.Y. & $\mathrm{S}$ & 3 & 158,5 & $\% 1,89$ & 5 & 235 & $\% 2,13$ \\
\hline Trakya & Sğ.K.Str.MalY & $\mathrm{S}$ & 3 & 208 & $\% 1,44$ & 5 & 244 & $\% 2,05$ \\
\hline Uşak & Davranış. Muh & $\mathrm{S}$ & 2 & 151 & $\% 1,32$ & 3 & 240 & $\% 1,25$ \\
\hline
\end{tabular}

Kaynak: İlgili yükseköğretim kurumlarının "Kaynakça" da belirtilen resmî web sitelerinden yararlanılarak yazarlar tarafindan oluşturulmuştur.

\subsubsection{Finans disiplini içerisinde yer alan diğer dersler}

Finans disiplini içerisinde yer alan az sayıdaki diğer derslere ilişkin dağılımlar Tablo 10'da verilmektedir. 
Tablo 10. Finans Disiplini İçerisinde Yer Alan Diğer Derslerin Dağılımları

\begin{tabular}{|c|c|c|c|c|c|c|c|c|}
\hline Üniversite & Dersin Adı & $\begin{array}{c}\text { Ders } \\
\text { Statï } \\
\text { Z/S }\end{array}$ & $\begin{array}{l}\text { Dersin } \\
\text { Kredisi }\end{array}$ & $\begin{array}{c}\text { Bölüm } \\
\text { Kredi } \\
\text { Toplamı }\end{array}$ & $\begin{array}{c}\text { Dersin } \\
\text { Bölüm } \\
\text { Kredi } \\
\text { Toplamına } \\
\text { Oranı (\%) }\end{array}$ & $\begin{array}{l}\text { Dersin } \\
\text { AKTS } \\
\text { Kredisi }\end{array}$ & $\begin{array}{c}\text { Bölüm } \\
\text { AKTS } \\
\text { Toplamı }\end{array}$ & $\begin{array}{c}\text { Dersin } \\
\text { Bölüm } \\
\text { AKTS } \\
\text { Toplamına } \\
\text { Oranı (\%) }\end{array}$ \\
\hline Afy.Sağ.B. & Fin.Perf.Dğ. & $\mathrm{S}$ & 2 & 201 & $\% 1,0$ & 2 & 240 & $\% 0,83$ \\
\hline Başkent & Fin.Perf.Dğ. & $\mathrm{S}$ & 3 & 169 & $\% 1,78$ & 5 & 240 & $\% 2,83$ \\
\hline Düzce & Fin.Perf.Dğ. & $\mathrm{S}$ & 3 & 159 & $\% 1,89$ & 4 & 240 & $\% 1,67$ \\
\hline İst. Meden. & S̆g. Kur.Fizib & $\mathrm{S}$ & 2 & 165 & $\% 1,21$ & 2 & 240 & $\% 0,83$ \\
\hline
\end{tabular}

\subsection{Ders Kredisi Bağlamında Değerlendirme}

Türkiye'de (K.K.T.C. dahil) ders müfredatına ulaşılan 67 bölümde; bir öğrencinin mezun olabilmesi için, alması gereken toplam ders kredisi ortalaması 158 kredi, muhasebe ve finans derslerinin bölüm başına düşen ortalama kredisi ise $\mathbf{1 4}$ ders kredisi olarak hesaplanmakta ve aşağıda yer almaktadır.

\begin{tabular}{|c|c|c|c|c|}
\hline $\begin{array}{c}(\mathbf{1}) \\
\text { Ulaşılan } \\
\text { Tüm Bölüm } \\
\begin{array}{c}\text { Kredi } \\
\text { Toplamı }\end{array}\end{array}$ & $\begin{array}{c}\text { Ulaşılan } \\
\text { Toplam } \\
\text { Bölüm } \\
\text { Sayısı }\end{array}$ & $\begin{array}{c}\text { (3) } \\
\text { Diploma İçin } \\
\text { Gerekli Ortalama } \\
\text { Ders Kredisi } \\
(\mathbf{3})=\frac{(\mathbf{1})}{(\mathbf{2})}\end{array}$ & $\begin{array}{c}\mathbf{( 4 )} \\
\text { Derslerin } \\
(\text { Muh-Fin) } \\
\text { Toplam } \\
\text { Kredisi }\end{array}$ & $\begin{array}{c}\text { (5) } \\
\text { Derslerin (Muh-Fin) } \\
\text { Ortalama Ders } \\
\text { Kredisi } \\
(\mathbf{5})=\frac{(4)}{(\mathbf{2})}\end{array}$ \\
\hline 10615 & 67 & $\mathbf{1 5 8}$ & 916 & $\mathbf{1 4}$ \\
\hline
\end{tabular}

\subsection{AKTS Bağlamında Değerlendirme}

Türkiye'de (K.K.T.C. dahil) AKTS kredisi bazında ders müfredatına ulaşılan 64 bölümde; bir öğrencinin mezun olabilmesi için, alması gereken toplam AKTS kredi ortalaması 237 AKTS, muhasebe ve finans derslerinin bölüm başına düşen ortalama AKTS kredisi ise 22 AKTS kredisi olarak hesaplanmakta ve aşağıda yer almaktadır.

\begin{tabular}{|c|c|c|c|c|}
\hline $\begin{array}{c}(1) \\
\text { Ulaşılan } \\
\text { Tüm Bölüm } \\
\text { Kredi } \\
\text { Toplamı }\end{array}$ & $\begin{array}{c}\text { Ulaşılan } \\
\text { Toplam } \\
\text { Bölüm } \\
\text { Sayısı }\end{array}$ & $\begin{array}{c}\text { (3) } \\
\text { Diploma İçin } \\
\text { Gerekli Ort.AKTS } \\
(3)=\frac{(1)}{(2)}\end{array}$ & $\begin{array}{c}\text { (4) } \\
\text { Derslerin } \\
\text { Muh-Fin) } \\
\text { Toplam } \\
\text { Kredisi }\end{array}$ & $\begin{array}{c}\text { (5) } \\
\text { Derslerin (Muh-Fin) } \\
\text { Ortalama AKTS } \\
(5)=\frac{(4)}{(2)}\end{array}$ \\
\hline 15194 & 64 & $\mathbf{2 3 7}$ & 1406 & $\mathbf{2 2}$ \\
\hline
\end{tabular}

\section{SONUÇ VE ÖNERILER}

Sağlık yönetimi bölümlerinde;

- Bir öğrencinin mezun olabilmesi için; ortalama 158 kredilik ders alması gerektiği, 
- Muhasebe ve finans derslerinin bölüm başına düşen ders kredisinin; ortalama 14 kredi olduğu,

- Muhasebe ve finans derslerinin ortalama kredisinin (14 kredi), mezun olması için alması gereken toplam ders kredisine (158) oranının \%8,86 olduğu görülmektedir.

Türkiye'de Sağlık Yönetimi alanında, lisans düzeyinde eğitim verilen bölümlerin ders müfredatları incelendiğinde;

- Muhasebe derslerine yeterince önem verildiği görülse de, muhasebe kaydı yapılan ya da toplanan bilgilerin sonuçlarının anlaşılmasını kolaylaştıran, gerekli karşılaştırmaların yapılmasını sağlayan ve muhasebenin önemli bir aracı durumunda olan, "Finansal Tablolar Analizi" ya da "Mali Tablolar Analizi"ne yönelik derslere fazlaca önem verilmemektedir. Müfredatlarında bu derslere seçmeli olarak yer veren bölüm sayısının 15 olduğu (15/67=\%22 oranında), zorunlu ders olarak verilen bölüm sayısının ise 7'de kaldığ 1 (7/67=\%10 oranında) görülmektedir.

- Tablo 3'te gruplandırılan; 5. Grup dersler içerisinde, "Stok/Stok Yönetimi” konusunun 1, 2, 3 ve 4'üncü grup, "Finansal (mali) Tablolar” konusunun 1, 3, 4 ve 5'inci grup, "Maliyet Analizleri" konusunun ise 2, 3, 4 ve 5'inci Grup derslerde \%80 oranında ortak konu olarak işlendiği sonucuna ulaşılmaktadır. Yine 2. Grup derslerde 45 konu başlığı içerisinde yer alan, "Maliyet Analizi", "Maliyetlerin Sınıflandırılması" ve "Maliyet Yöntemleri, Sistemleri” konularını içeren 3 (üç) konu başlığının, 3. Grup derslerde yer alan 36 konu başlığından 3'ü ile ortak başlıkta ele alındığı görülmektedir.

- Sağlık yöneticilerinin karar verme aşamasında gerek duyacakları ayrıntılı bilgileri sağlamada önemli bir yere sahip olan "Yönetim Muhasebesi"ne yönelik derslere de fazla önem verilmemektedir. "Yönetim Muhasebesi" dersini, müfredatlarında seçmeli ders statüsünde yer veren bölüm sayısının 10 olduğu (10/67=\%15 oranında), zorunlu ders olarak yer veren bölüm sayısının ise 6 olduğu (6/67=\%9 oranında), görülmektedir.

- Hızlı nüfus artışı, teknolojik gelişmeler ve sanayileşme sonucunda, kıt olan çevresel kaynakların korunması ve etkin kullanılmasına yönelik olarak, çevre maliyetleri ve çevre muhasebesinin son yıllarda önemi artmaya başlamıştır. Özellikle "Yeşil Hastane" olarak adlandırılan çevreci sağlık kurumları, muhasebenin sosyal sorumluluk kavramı gereğince çevre muhasebesi yardımıyla, doğaya verdikleri zararı ve etkilerini tespit etmekte, çevre maliyetlerini hesaplayarak, sınıflandırmakta ve raporlandırmaktadır. Sağlık yönetimi alanında lisans düzeyinde eğitim verilen bölümlerin müfredatları incelendiğinde, her ne kadar atık yönetimi, çevre çalışmaları, ekolojik okuryazarlık ve sürdürülebilirlik, sağlık ve çevre, çevre koruma vb. gibi az sayıda seçmeli derslerin bulunduğu görülse de, hiçbir bölümde "Çevre Maliyetleri" ya da "Çevre Muhasebesi”ne yönelik bir derse rastlanılamamaktadır.

- Son yıllarda sayıları hızla artan özel hastaneler, neredeyse tüm sağlık sigortalı hastalara kapılarını açmıştır. Özel hastaneler tarafından verilen sağlık hizmetleri, Kördeve'ye göre (Kördeve, 2017: 1-4) MEDULA olarak adlandırılan sistemle, elektronik bir biçimde bilgiler toplanarak faturalandırılmakta ve hizmet ödemeleri devlet adına Sosyal Güvenlik Kurumu tarafından yapılmaktadır. Özel sağlık kuruluşlarında, hastaların, sağlık kuruluşuna girmesinden taburcu olmasına kadar geçen tüm süreçte verilen hizmetin tahakkuku, hekimlerin işe başlama süreçleri, fiyatlandırma politikaları, anlaşmalı 
kurumları, özel sağlık sigortaları, iş kazaları vb. birçok önemli işlemin takibini gerekmektedir. Bu görev her geçen gün önemi artan "Medikal Muhasebe" uzmanları tarafından yerine getirilmektedir. Sağlık yönetimi alanında lisans düzeyinde eğitim verilen bölüm müfredatlarının sadece 1'inde "Medikal Muhasebe" dersi seçmeli ders statüsünde yer almaktadir.

Yukarıda sıralanan bulgu ve sonuçlar bağlamında çalışmada aşağıdakiler önerilmektedir:

- "Sağlık Yönetimi” bölümü müfredatlarında, ilgili yükseköğretim kurumlarının imkânları ölçüsünde; "Finansal Tablolar Analizi”, "Mali Tablolar Analizi”, "Yönetim Muhasebesi”, "Çevre Maliyetleri", "Çevre Muhasebesi" ve "Medikal Muhasebe" derslerine yer verilmelidir.

- Farklı isimlerde eğitim verilen ancak birbirine yakın içerikleri bulunan ders isimlerinde bir standart sağlanmalıdır.

- Ders gruplarının müfredatlarında yer alan konu başlıklarının, derslerin ilgisine göre gözden geçirilerek ele alınmalıdır.

- Sağlık Yönetimi bölümlerinin, "Fakültelerde mi?” yoksa "Yüksekokullarda mı?” yer alması gerektiğine karar verilmelidir.

- Şayet cevap "Fakültelerde" olacak ise "Sağlık Bilimleri Fakültelerinde mi?" yoksa “İktisadi ve İdari Bilimler Fakültelerinde mi?” bulunması gerektiğine karar verilerek yine bir standart oluşturulmalıdır.

Türkiye'de lisans düzeyinde eğitim verilen “Sağlık Yönetimi” bölümlerinden mezun olacak geleceğin sağlık yöneticileri, muhasebe ve finans ders yelpazesinin geniş tutulması ile teori ve pratiği birleştirebilecek aynı zamanda yöneticilik ve liderlik niteliklerine sahip olabileceklerdir.

\section{KAYNAKÇA}

AYANOĞLU, Y., ABUHANOĞLU, H. ve TEKE, A. (2013). "Sağlık Hizmetleri Yönetimi Eğitiminde Muhasebe ve Finansman Derslerinin Önemi”, Gazi Üniversitesi İ.İ.B.F. Dergisi, 15(1), 1-19 [http://dergipark.gov.tr/gaziuiibfd/issue/28314/300881, 21.01.2019].

BİÇER, B. E., AYDIN, Y. ve ILIMAN, E. (2018). “Sağlık Yönetimi Öğrencilerinin Muhasebe Dersine Karşı Tutumlarının Başarı Düzeylerine Etkisi Üzerine Bir Araştırma”. Tokat Gaziosmanpaşa Üniversitesi Sosyal Bilimler Araştırmaları Dergisi, Yaz 2018 13(1), 179-199

[https://www.researchgate.net/publication/330385611_SAGLIK_YONETIMI_OGRE NCILERININ_MUHASEBE_DERSINE_KARSI_TUTUMLARININ_BASARI_DUZ EYLERINE_ETKISI_UZERINE_BIR_ARASTIRMA, 08.03.2019].

ÇíL, K. S., DOĞAN, E. ve TAŞ, E. (2016). "Sağlık Yönetimi Bölümü Öğrencilerinin Muhasebe Derslerindeki Başarılarını Etkileyen Faktörlerle İlgili Görüşlerini Belirlemeye Yönelik Bir Araştırma (Ankara Üniversitesi ve Gazi Üniversitesi Örneği)". Mehmet Akif Ersoy Üniversitesi S.B.E. Dergisi, 8 (16), 222-252 
[http://dergipark.ulakbim.gov.tr/makusobed/article/view/5000196198/5000174300, 21.01.2019].

ÇİL, K. S., ŞENAY, F., DURSUN, T. N. ve KAHRAMAN, G. (2018). "Türkiye'deki Üniversitelerde Sağlık Yönetimi Yüksek Lisans Eğitiminde Muhasebe ve Finansman Dersleri Üzerinde Bir Araştırma". Marmara Üniversitesi Öneri Dergisi, 13(49), 149166.

[http://dergipark.gov.tr/download/article-file/429947, 21.01.2019].

ÇíMEN, M. (2010). “Sağlık Yönetimi ve Sağlık Yönetimi Eğitimi”. Acıbadem Üniversitesi Sağlık Bilimleri Dergisi, 1(3), 136-139.

DALKILIÇ, S. (2015). [Danışman: MALHAN, S.] Sağlık Kurumları İşletmeciliği Lisans Programlarının Müfredatlarının İncelenmesi. Ankara: Başkent Üniversitesi Sosyal Bilimler Enstitüsü Yayımlanmamış Yüksek Lisans Tezi, 1-144.

FRNKLER, S. A. and WARD, D. M. (2006). Accounting Fundamentals for Health Care Management. Sudbury Massachusetts: Jones and Barlett Publishers.

KAHYAOĞLU, F., YANIK, A. ve TENGİLiMOĞLU, D. (2013). "Batı Akdeniz Bölgesi Sağlık Kurumları Yöneticilerinde Mesleki Yeterliliklerinin Belirlenmesine Yönelik Bir Çalışma”. Elektronik Meslek Yüksekokulları Dergisi (EJOVOC) 3(1), 15-27.

KAPTANOĞLU, A. Y. (2011). Sağlık Yönetimi. KAPTANOĞLU, A. Y. (Ed.), Sağlık Yönetimi, İstanbul: Beşir Kitabevi, 14-89.

KÖRDEVE, M. (2017). “Sağlık Ödemelerinde Yeni Bir Kavram: Medikal Muhasebe”. Ç.Ü. Sosyal Bilimler Enstitüsü Dergisi, 26-12, 1-13 [http://dergipark.gov.tr/cusosbil/issue/31880/349999, 21.01.2019)].

ÖZSARI, S. H. ve SÖYLET, Y. (2013). "Yükseköğretimde Sağlık Eğitimi İçin Öneriler”. Sağlık Düşüncesi ve Tip Kültürü Platformu Dergisi, 25, 28-29. [http://www.sdplatform.com/Dergi/666/ Yuksekogretimde-saglik-egitimi-icinoneriler.aspx, 08.03.2019)].

WALSHE, K. and SMITH, J. (2006). "Healthcare Management", K. WALSHE and J. SMITH (Eds.), Introduction: The Current and Future Challenges of Healthcare Management, England; Open University Press (1-9).

WHO (2000). The World Health Report 2000: Health Systems: Improving Performance, Genava, 1-19 [https://www.who.int/whr/2000/en/whr00_ch1_en.pdf?ua=1, 21.01.2019)].

http://akts.hacettepe.edu.tr/ders_listesi.php?prg_ref=PRGRAM_00000000000000000000000 $3 \&$ birim_kod=486\&submenuheader $=2 \&$ prg_kod=486\&programduzey $=2 \&$ dil_kod=1, 16.01.2019.

http://angora.baskent.edu.tr/bilgipaketi/?dil=TR\&menu=akademik\&inner=katalog\&birim=17 $5,16.01 .2019$.

http://asyo.afsu.edu.tr/, 16.01.2019.

https://bau.edu.tr/icerik/3279-saglik-yonetimi-lisans-programi, 16.01.2019. 
http://bbs.ankara.edu.tr/Ders_Plani.aspx?bno=1436\&bot=33, 16.01.2019.

http://bilgipaketi.hitit.edu.tr/Mufredat.aspx, 16.01.2019

http://bloustein.rutgers.edu/wp-content/uploads/2013/12/EJBPPP-501-HealthAdmin-20171.pdf, 16.01.2019.

https://bologna.avrasya.edu.tr/, 16.01.2019.

http://bologna.nisantasi.edu.tr/Home/DetailPrograms/32, 16.01.2019.

http://catalog.jmu.edu/preview_program.php?catoid=10\&poid=3461\&returnto=578, 16.01.2019.

http://catalog.rider.edu/undergraduate/colleges-schools/business-administration/majorsminors-certificates/health-care-management/\#academicplantext, 16.01.2019.

http://catalog.springfield.edu/preview_program.php?catoid=77\&poid=2994\&returnto=2088\& _ga=2.166072059.410240661.1546520199-1569917200.1546520199, 16.01.2019.

http:/catalog.uab.edu/undergraduate/schoolofhealthprofessions/healthservicesadministration/ health_care_management/\#courseinventory, 03.01.2019.

http://cdn.istanbul.edu.tr/FileHandler2.ashx?f=mufredat-ders-listesi-sagl.pdf, 16.01.2019.

http://derspaketleri.erzincan.edu.tr/getProgram.aspx?mod=1\&program=360\&Adi=System.X ml.XmlElement, 16.01.2019.

https://ebs.aydin.edu.tr/index.iau?Page=BolumDersleri\&BK=523\&DersTuru=0\&ln=tr, 16.01.2019.

http://ebs.beykent.edu.tr/2015/TR/Akademik-Programlar/Lisans/1355/1360/1361/Ders-Planive-Yapisi, 16.01.2019.

http://ebs.omu.edu.tr/ebs/program.php?dil=tr\&mod=1\&Program=4865\#mf, 16.01.2019.

https://ebs.sakarya.edu.tr/BirimDetay/DersPlan/1136, 16.01.2019.

https://ects.bilgi.edu.tr/Department/Curriculum?catalog_departmentId=50705, 16.01.2019.

http://eos.trakya.edu.tr/Pages/CoursePlan.aspx?lang=tr-TR\&academicYear=2018\&facultyId

$=10 \&$ programId=5\&menuType=unit, 16.01.2019.

http://gbs.gelisim.edu.tr/ders-plani-5-102-1, 06.01.2019.

http://health.gau.edu.tr/saglik_yonetimi_bolumu.html, 06.01.2019.

http://hm.fhs.ieu.edu.tr/tr/curr, 16.01.2019.

http://iibf.ahbv.edu.tr/posts/view/title/iktisadi-idari-bilimler-bilgi-paketi-104705?siteUri=iibf, 06.01.2019.

https://iibf.istinye.edu.tr/bolumler/saglik-yonetimi/ders-plani/, 16.01.2019.

http://iibf.sdu.edu.tr/assets/uploads/sites/271/files/saglik-yonetimi-ders-plani-13092018.pdf, 16.01.2019. 
https://mebis.medipol.edu.tr/programbilgi/program/8, 16.01.2019.

https://mebis.medipol.edu.tr/programbilgi/program/10123, 16.01.2019.

https://neu.edu.tr/akademik/fakulteler/saglik-bilimleri-fakultesi/bolumler/saglik-kurumlariyonetimi-bolumu/dersler/?lang=tr, 16.01.2019.

https://newbury.edu/academics/our-schools/roger-a-saunders-school-of-business-andhospitality-management/health-care-management, 16.01.2019.

https://obs.aksaray.edu.tr/oibs/bologna/start.aspx?gkm=065335500311013111434460344323 $8808344563836833291378053111238960,16.01 .2019$.

https://obs.bandirma.edu.tr/oibs/bologna/start.aspx?gkm=07623660035505389123892033324 $31101366843836835485389203333637840,06.01 .2019$.

https://obs.cumhuriyet.edu.tr/oibs/bologna/start.aspx?gkm=081434400377073891238920355 $4033303311143313836582378053111233360,16.01 .2019$.

https://obs.gop.edu.tr/oibs/bologna/start.aspx?gkm=014533300333033891237805366483880 8355703627637679322303111234480, 16.01.2019.

https://obs.gumushane.edu.tr/oibs/bologna/start.aspx?gkm=054738800311013557038920355 4038808366843313834388311153444831120, 06.01.2019.

https://obs.kilis.edu.tr/oibs/bologna/start.aspx?gkm=097537700333033668433345311083330 $3377983836833291366903111235600,16.01 .2019$.

https://obs.kku.edu.tr/oibs/bologna/start.aspx?gkm=032236600322023222838920322163770 $7322283836832194378053667235600,16.01 .2019$.

https://obs.kmu.edu.tr/oibs/bologna/start.aspx?gkm=096538800311013891233345388643660 $632228214636582366903556034480,16.01 .2019$.

https://obs.mehmetakif.edu.tr/oibs/bologna/start.aspx?gkm=072538800311013891236690333 $2438808311143418436582311153889637840,16.01 .2019$.

https://obs.usak.edu.tr/oibs/bologna/start.aspx?gkm=056034400355053334237805388643110 $136684362762197355753333635600,16.01 .2019$.

https://obs.ybu.edu.tr/oibs/bologna/start.aspx?gkm=053833300388083222833345311083770 $732228214633291322303889637840,16.01 .2019$.

https://ogrenciotomasyonu.alparslan.edu.tr/oibs/bologna/start.aspx?gkm=0970366003880835 $570355753443233303344563627634388389203556037840,06.01 .2019)$.

http://oibs.mersin.edu.tr/bologna/?id=/courses\&program=1320\&sinif=1, 16.01.2019.

http://sablon.mu.edu.tr/Icerik/syb.mu.edu.tr/Duyuru/ders.pdf, 16.01.2019.

http://saglikyonetimi.ksu.edu.tr/Default.aspx?SId=8410, 16.01.2019.

https://saglikyonetimi.medeniyet.edu.tr/tr/ogrenci/ders-mufredati, 16.01.2019.

http://sbf.bezmialem.edu.tr/tr/PublishingImages/Sayfalar/saglik-yonetimi-bolumu/sy-dersplani/6-\%202018-2019-SAgLiK-YoNETiMi-DERS-PLANi.pdf, 06.01.2019. 
http://sbf.marmara.edu.tr/bolumler/saglik-yonetimi-bolumu/ders-icerikleri/, 16.01.2019.

http://sbf.ogu.edu.tr/Sayfa/Index/58/saglik-yonetimi-bolumu-fakulte-ders-icerikleri, 16.01.2019.

https://sis.biruni.edu.tr/oibs/bologna/start.aspx?gkm=08163440036606344563892037756366 $06333423627637679355753667235600,16.01 .2019$.

https://sis.uskudar.edu.tr/oibs/bologna/start.aspx?gkm=0772322003550533342366903664832 $20236684214635485322303889635600,16.01 .2019$.

http://syo.klu.edu.tr/dosyalar/birimler/syo/dosyalar/dosya_ve_belgeler/Ust_Menu/Ogrenci_M enu/Ders_Icerikleri/SA_LIK_YONET__M_2015.pdf, 16.01.2019.

https://ubs.ikc.edu.tr/AIS/OutcomeBasedLearning/Home/Index?id=379, 16.01.2019.

http://ubys.ardahan.edu.tr/AIS/OutcomeBasedLearning/Home/Index?id=2007, 06.01.2019.

https://www.acibadem.edu.tr/saglikyonetimibolumu-mufredat, 06.01.2019.

https://www.anadolu.edu.tr/acikogretim/turkiye-programlari/acikogretim-sistemindekiprogramlar/saglik-yonetimi, 16.01.2019.

https://www.arel.edu.tr/saglik-bilimleri-yuksekokulu/saglik-yonetimi-bolumu/dersler, 16.01.2019.

https://www.ataaof.edu.tr/Program/DersIcerik/90, 16.01.2019.

https://www.bayburt.edu.tr/tr/egitim-ve-ogretim-plani-mufredat-1, 06.01.2019.

http://www.ciu.edu.tr/tr/akademik/yuksekokullar/saglik-bilimleriyuksekokulu/bolumler/saglik-yonetimi/müfredat, 16.01.2019.

http://www.dicle.edu.tr/Contents/1980060d-dc94-4bf8-970d-55d032d630af.pdf, 06.01.2019.

https://www.emu.edu.tr/tr/programlar/saglik-yonetimi-lisans-programiturkce/812?tab=curriculum, 16.01.2019.

http://www.if.duzce.edu.tr/Dokumanlar/if/Saglik\%20Yonetimi\%20Bolumu\%20Ders\%20Plan i-Guncel.pdf, 06.01.2019.

https://www.izu.edu.tr/akademik/fakulteler/saglik-bilimleri-fakultesi/bolumler/saglikyonetimi, 16.01.2019.

http://www.katalog.ktu.edu.tr/DersBilgiPaketi/semester.aspx?pid=3035\&lang=1\&sid=10, 16.01.2019.

http://www.kent.edu.tr/content/files/Akademik/Bolum-Mufredati/saglik-yonetimi.pdf, 16.01.2019.

https://www.konya.edu.tr/storage/images/department/saglikbilimleri/belgeler/mufredat/saglik _yonetimi.pdf, 16.01.2019.

https://www.mcphs.edu/academics/school-of-healthcare-business/healthcarebusiness/healthcare-mangement-bs, 03.01.2019. 
http://www.sbu.edu.tr/FileFolder/Dosyalar/cf33f43b/2018_9/saglik-yonetimi-mufredatb5f9bd6f.pdf, 16.01.2019.

http://www.selcuk.edu.tr/saglik_bilimleri_fakultesi/saglik_yonetimi/bolum_dersleri/tr, 16.01.2019.

http://www.toros.edu.tr/dosya/238/dokuman/2017-09-19-2017-2018-SAgLIK-YoNETiMi-

DERS-MuFREDATI.pdf, 16.01.2019.

http://www.yeniyuzyil.edu.tr/Bolumler/SaglikYonetimi/Sa\%C4\%9Fl\%C4\%B1k\%20Y\%C3\% B6netimi\%20B\%C3\%B61\%C3\%BCm\%C3\%BC-2018-

$2019 \% 20 \mathrm{D} \% \mathrm{C} 3 \% \mathrm{~B} 6 \mathrm{rt} \% 20 \mathrm{Y} \% \mathrm{C} 4 \% \mathrm{~B} 111 \% \mathrm{C} 4 \%$

B1k\%20M\%C3\%BCfredat.pdf, 16.01.2019. 